Review

\title{
Wine, Polyphenols, and Mediterranean Diets. What Else Is There to Say?
}

\author{
Celestino Santos-Buelga *DiD, Susana González-Manzano (D) and Ana M. González-Paramás \\ Grupo de Investigación en Polifenoles (GIP-USAL), Universidad de Salamanca, E-37007 Salamanca, Spain; \\ susanagm@usal.es (S.G.-M.); paramas@usal.es (A.M.G.-P.) \\ * Correspondence: csb@usal.es; Tel.: +34-923-294-500
}

Citation: Santos-Buelga, C.;

González-Manzano, S.;

González-Paramás, A.M. Wine,

Polyphenols, and Mediterranean Diets. What Else Is There to Say? Molecules 2021, 26, 5537. https:// doi.org/10.3390/molecules26185537

Academic Editors: Norbert Latruffe, Paula Silva and Francesco Cacciola

Received: 25 June 2021

Accepted: 9 September 2021

Published: 12 September 2021

Publisher's Note: MDPI stays neutral with regard to jurisdictional claims in published maps and institutional affiliations.

Copyright: (C) 2021 by the authors Licensee MDPI, Basel, Switzerland. This article is an open access article distributed under the terms and conditions of the Creative Commons Attribution (CC BY) license (https:/ / creativecommons.org/licenses/by/ $4.0 /)$.

\begin{abstract}
A considerable amount of literature has been published claiming the cardiovascular benefits of moderate (red) wine drinking, which has been considered a distinguishing trait of the Mediterranean diet. Indeed, red wine contains relevant amounts of polyphenols, for which evidence of their biological activity and positive health effects are abundant; however, it is also well-known that alcohol, even at a low level of intake, may have severe consequences for health. Among others, it is directly related to a number of non-communicable diseases, like liver cirrhosis or diverse types of cancer. The IARC classifies alcohol as a Group 1 carcinogen, causally associated with the development of cancers of the upper digestive tract and liver, and, with sufficient evidence, can be positively associated with colorectum and female breast cancer. In these circumstances, it is tricky, if not irresponsible, to spread any message on the benefits of moderate wine drinking, about which no actual consensus exists. It should be further considered that other hallmarks of the Mediterranean diet are the richness in virgin olive oil, fruits, grains, and vegetables, which are also good sources of polyphenols and other phytochemicals, and lack the risks of wine. All of these aspects are reviewed in this article.
\end{abstract}

Keywords: olive oil; resveratrol; alcohol; phytochemicals; tyrosol

\section{Introduction}

In November 2010, following a transnational nomination submitted by Spain, Greece, Italy, and Morocco, the UNESCO decided to inscribe the Mediterranean Diet as an Intangible Cultural Heritage of Humanity (https: / / ich.unesco.org/en/Decisions/5.COM/6.41, accessed on 1 September 2021), further enlarged in December 2013 with the incorporation of three other countries: Croatia, Cyprus, and Portugal (https://ich.unesco.org/en/ Decisions/8.COM/8.10, accessed on 1 September 2021). In its decision, the UNESCO recognized the Mediterranean diet (MedDiet) as "a set of skills, knowledge, practices and traditions ranging from the landscape to the table, including the crops, harvesting, fishing, conservation, processing, preparation and, particularly, consumption of food (... ) characterized by a nutritional model that has remained constant over time and space, (... ) always respecting beliefs of each community."

Consistent associations of this Mediterranean dietary pattern with cardiovascular benefits were first reported in the 1960's from the earlier results of the Seven Countries Study (https: / / www.sevencountriesstudy.com/, accessed on 1 September 2021), describing significantly lower mortality rates and incidences of cardiovascular diseases in the Italian, Greek, and Croatian cohorts than in the rest of the included (non-Mediterranean) countries [1]. Further confirmation of these outcomes was obtained from the HALE project (Healthy Ageing - a Longitudinal study in Europe), analysing data on lifestyle, dietary, and biological determinants of healthy ageing from individuals of 13 European countries, collected from the Seven Countries, as well as the FINE (Finland, Italy, Netherlands Elderly study) and SENECA (Survey in Europe on Nutrition in the Elderly-a Concerted Action) 
prospections. It was found that adherence to a MedDiet, together with a healthful lifestyle (i.e., being physically active, non-smoking for more than 15 years, and moderate alcohol intake) was associated with a more than 50\% lower rate of all-causes and cause-specific mortality, including coronary heart disease (CHD), cardiovascular disease (CVD), and cancer [2].

Similar observations were made from many other epidemiological and intervention studies. A comprehensive analysis of the results from observational studies and randomised clinical trials - comprising a total population of over 12,800,000 individuals—was made by Dinu et al. [3], concluding that there was robust evidence to suggest that greater adherence to a Mediterranean diet style is associated with a reduced risk of overall mortality, CVD, overall cancer incidence, neurodegenerative diseases, and type-2 diabetes. In a previous screening across intervention trials, Serra-Majem et al. [4] also concluded that there was good evidence to suggest that a MedDiet improves the lipid profile, endothelial function, and blood pressure, despite the fact that the authors also highlighted that there were discrepancies on how the different studies defined and formulated the Mediterranean diet.

Indeed, the Mediterranean diet does not constitute a close and unique nutritional model, but it is rather a compendium of diverse dietary habits traditionally followed by countries around the Mediterranean basin. In spite of their heterogeneity, some common patterns are observed across these countries, namely a high consumption of plant products such as fruits, vegetables, legumes, and nuts, as well as cereals (bread, pasta, rice, and whole grains); a moderate intake of dairy products, fish, poultry, and eggs as main protein sources, with small amounts of red and processed meat; the use of olive oil as a main fat source and water as a beverage of choice. Additionally, the diet is characterized by infusions and optional moderate amounts of wine taken with meals, and a preference for seasonal, fresh, and locally low-processed products. This was summarized in the Pyramid of the Mediterranean diet proposed by the "Fundación Dieta Mediterránea" (https:/ / dietamediterranea.com/en/fundacion, accessed on 1 September 2021) (Figure 1).

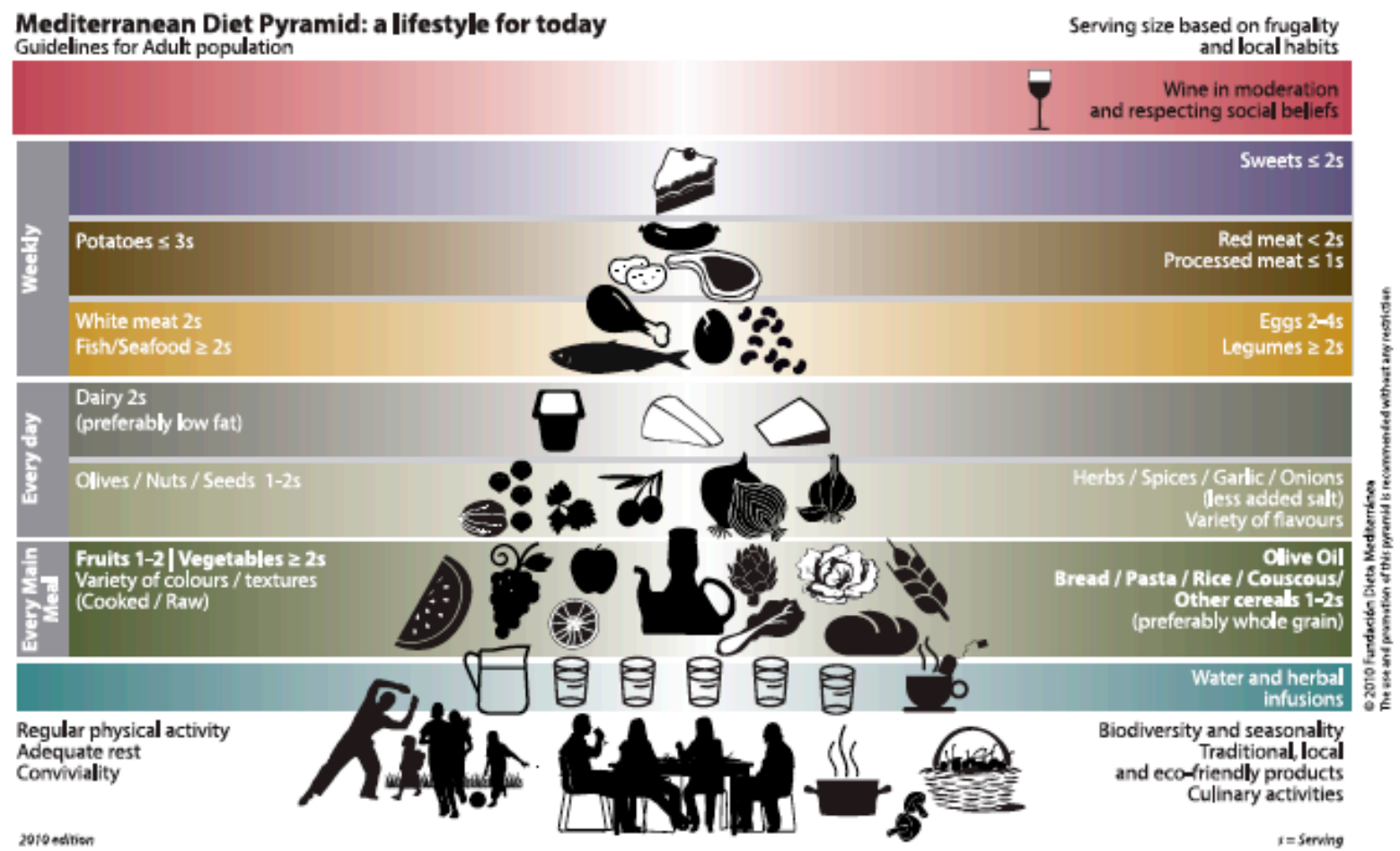

Figure 1. Pyramid of the Mediterranean diet (https:/ / dietamediterranea.com/en/fundacion, accessed on 1 September 2021). 
Relevant nutrients and bioactive compounds contributed by the main food items in the Mediterranean diet are summarized in Table 1.

Table 1. Main bioactive compounds provided by representative foodstuffs of the Mediterranean diets.

\begin{tabular}{cc}
\hline Food Item & Main Bioactive Compounds \\
\hline Fresh fruit & Vitamin C, polyphenols, dietary fiber \\
Citrus fruits & Vitamin C, flavonoids \\
Nuts & Polyunsaturated fatty acids, phytosterols, vitamin E \\
Whole grains & Complex carbohydrates, dietary fiber \\
Legumes & Proteins, dietary fiber, saponins \\
Raw vegetables & Hydrosoluble vitamins, carotenoids \\
(tomatoes, carrots) & Folic acid, dietary fiber \\
Leafy green vegetables & Glucosinolates \\
Cruciferous & n-3 Long-chain polyunsaturated fatty acids, high-quality \\
Fish & proteins \\
Cairy products & Calcium, bioactive peptides, high-quality proteins \\
Eggs and poultry & High-quality proteins \\
Extra virgin olive oil & Monounsaturated fatty acids, polyphenols, phytosterols \\
Red wine & Polyphenols \\
Allium compounds & Sulphur compounds \\
\hline
\end{tabular}

The dietary patterns of the MedDiet have been suggested to likely overlap with those for optimal prevention of both cardiovascular diseases and cancer. Thus, it is considered that, whatever the particular food choices, Mediterranean diets provide adequate intakes of total fat and long-chain polyunsaturated fatty acids, dietary fiber, antioxidant vitamins, carotenoids, and polyphenols, as well as a balanced n-6/n-3 ratio of essential fatty acids and low amounts of saturated fatty acids (SFA) [5-7]. All of these characteristics are related to beneficial effects on endothelial and cardiovascular function. Furthermore, monounsaturated fatty acids (MUFA) present in olive oil (i.e., oleic acid) are acknowledged to improve the blood lipid profiles [8]. Actually, a common and consistent feature of the MedDiet seems to be the existence of a high MUFA/SFA ratio (estimated to be around 2.0 on average) [5], which has been significantly associated with low CVD mortality and overall mortality [9]. Complex carbohydrates and dietary fiber contributed by whole grain products, legumes, and vegetables have also been related with gut health and protection against different cancers, especially colorectal cancer $[10,11]$. There are also glucosinolates and other organosulphur compounds present in cruciferous vegetables and allium condiments, which have acknowledged anti-inflammatory properties [12]. Another feature of the MedDiet which is usually associated with its health-promoting properties is the supply of significant amounts of different classes of antioxidant polyphenols, which are even higher than those of other dietary antioxidants, such as vitamin C, vitamin E, or carotenoids [13]. Regular intake of these compounds has been related to beneficial effects on the lipids profile, blood pressure, glucose metabolism, adiposity, or inflammatory processes, and are also associated with a reduction in the incidence of several chronic diseases, like cardiovascular diseases, type-2 diabetes, metabolic syndrome, neurodegenerative disorders, or different cancers [14-16].

The purpose of the present review is to discuss the role of wine and wine polyphenols in the health benefits of the Mediterranean diet. A particular mention is made to resveratrol, owing to the special attention that has been paid to its possible contribution to the beneficial effects of moderate wine intake, as associated with the MetDiet. Reference is also made to olive oil as a distinguishing food in the MetDiet with claimed health benefits, which have been proposed to rely, at least in part, on its characteristic polyphenols, which are different to those present in wine. 


\section{Polyphenols as Key Components of Mediterranean Diets}

Plant phenolic compounds, commonly referred to as polyphenols, are widespread in the diet, and are nowadays considered, at least in part, responsible for the health protective effects of fruit and vegetable-rich diets. They can be classified in two major classes: flavonoids and non-flavonoids, including phenolic acids (i.e., hydroxybenzoic and hydroxycinnamic acids and their derivatives), stilbenes, and lignans (Figure 2), as well as phenolic alcohols and their secoiridoid derivatives.

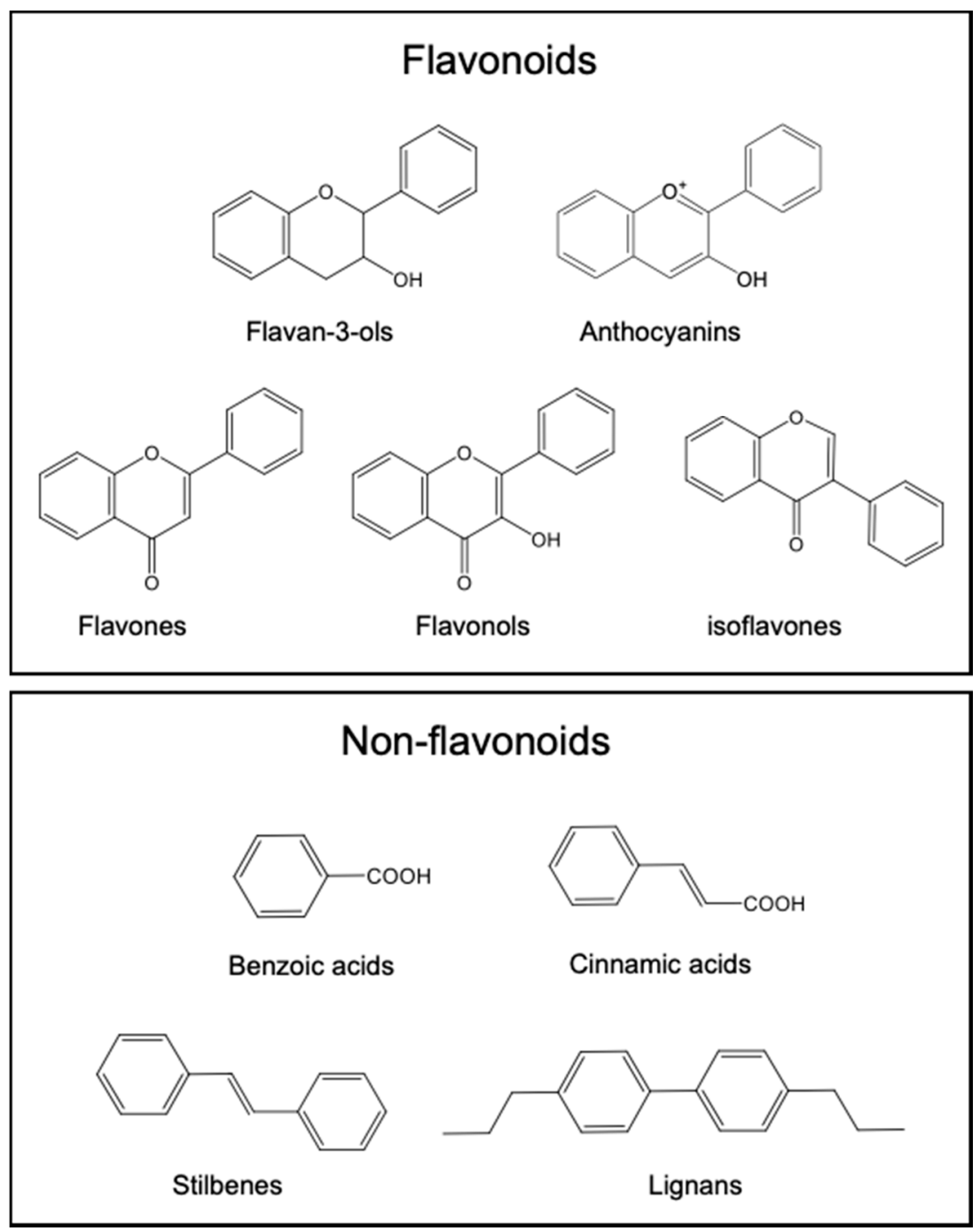

Figure 2. Core structures of the main classes of plant phenolic compounds.

The dietary intake of polyphenols largely varies among individuals, and is estimated to range from a few hundred $\mathrm{mg} /$ day to more than $1800 \mathrm{mg}$ /day depending on the region and target population, as well as the methodology used for the assessment [17]. Hydroxycinnamic acid esters, namely caffeoylquinic acids and flavan-3-ols oligo/polymers (i.e., proanthocyanidins), are usually reported as the most important groups of consumed polyphenols, followed by anthocyanins and flavonols [17]. In general, the contribution of phenolic acid derivatives and flavonoids tends to be equilibrated, although there are differences across countries and population groups as a function of their dietary habits. For example, there are higher proportions of flavonoids in Mediterranean regions, while phenolic acids would predominate in non-Mediterranean countries [18-21]. The main food sources for individual polyphenols tend to be similar among individuals, with coffee, tea, and fruits as major items, and vegetables and red wine in a second range [17]. It is 
suggested that moderate red wine drinkers consume polyphenols at levels well above the population average [6].

Despite the fact that the antioxidant capacity of polyphenols is well-substantiated in vitro and has been recurrently associated in the literature to their health effects, the little bioavailability and large biotransformation of most polyphenols in the organism raise doubts that this activity can have a primary role on their in vivo effects [17]. Although this possibility might not be discarded for particular compounds or situations, nowadays, other alternatives are considered to contribute to the in vivo effects of polyphenols. For example, they could act as modulators of gene expression and intracellular signaling cascades involved in cell function and protection [22,23]. There is also increasing evidence about the crucial role of the interactions between polyphenols and gut microbiota as a mainstay to explain the health benefits of their consumption. A vast majority of the consumed polyphenols reach the large intestine unaltered, where they can be catabolized by the colonic microflora to a variety of metabolites [24,25]. Some of these metabolites can be biologically active, and be responsible for the activity associated with their parent polyphenols. Among others, this would be the case of tyrosols, produced from oleuropein and related phenolics from olive oil, with putative effects against some types of cancer [26]; urolithins, involved in the lipid-lowering effects and improvement in the cardiovascular risk biomarkers of ellagitannins [27]; or estrogenic $S$-equol, enterodiol, and enterolactone, derived from soy isoflavones [28] and lignans [29], respectively. The role of other metabolites, such as phenolic acids and aldehydes resulting from the bacterial breakdown of flavonoids, is still uncertain, although they might be expected to contribute to a part of their effects, both at the local and systemic level. Additionally, unabsorbed polyphenols and phenolic metabolites can also have an impact on the composition of the gut microbiota, acting as prebiotic-like compounds. For instance, they have been suggested to be able to decrease the Firmicutes/Bacteroidetes ratio [30,31], linked to obesity trends in humans [32], and increase the abundance of beneficial Bifidobacteria and Lactobacilli spp. [30,33-35], while producing a reduction in the levels of Bacteroides, Streptococci, Enterobacteriacae, or Clostridia [36,37]. In the end, several mechanisms might be involved in the biological effects of polyphenols and contribute to their health benefits. This is a current active field of research that is rapidly progressing, so that advances are expected in coming years [38].

Most of the available information on the biological activity and effects of the phenolic compounds has been obtained from in vitro, ex vivo, and animal studies, whereas data directly obtained in humans are scarce, and restricted, in general, to short-term intervention trials on a reduced number of people. Some attempts have been made in Mediterranean cohorts, whose results support the role of polyphenol-rich foods to the health benefits of the Mediterranean diet $[16,19,39,40]$. Nevertheless, assessing the precise contribution of dietary polyphenols to those benefits remains complex, owing to the fact that the same food sources are also rich in other bioactives, such as vitamins, minerals, dietary fiber, or other antioxidants, which should also contribute to the health effects [17].

\section{Olive Oil}

Olive oil, and especially virgin olive oil (VOO), is one of the products most usually associated with the health properties of the MedDiet. Its regular consumption has been claimed to provide benefits against a number of disease conditions, such as atherosclerosis, diabetes mellitus, obesity, cancer, or neurodegenerative diseases [41]. It is well-known that olive oil is very rich in monounsaturated fatty acids-mainly oleic acid, accounting for up to $80 \%$ of its total fatty acids-with acknowledged positive effects on the profiles of plasmatic lipoproteins, triglycerides, and platelet aggregation [42,43], which has been linked to protection against cardiovascular and neurodegenerative diseases [44]. Actually, the EFSA has approved health claims regarding the positive effects of "monounsaturated fatty acids (mainly oleic acid)", "oleic acid", and "extra virgin olive oil" in the maintenance of normal blood LDL-cholesterol concentrations and the maintenance of normal (fasting) 
blood concentrations of triglycerides, when replacing saturated fatty acids (SFAs) in foods or diets [8].

In addition to its fatty acid profile, VOO also contains a series of biologically active polyphenols, in a concentration that oscillates within a large range from 50 to $1000 \mathrm{mg} / \mathrm{kg}$, depending on the olive cultivar and ripening stage, environmental factors (climate, altitude, agricultural practices), extraction techniques, storage conditions, and time [45]. It has been estimated that they may account for up to around $2 \%$ of total olive oil weight, contributing not only to olive oil's health properties, but also to its taste and fatty acid stability against oxidation [46].

VOO possesses a unique phenolic composition mainly consisting of secoiridoid derivatives, the most abundant one being oleuropein, the glucosylated form of 3,4-dihydroxyphenylethanol-elenolic acid (3,4-DHPEA-EA). Oleuropein is considered the main compound contributing to the bitterness of olives. Other related secoiridoids are the ligstroside aglycone (p-HPEA-EA) and the dialdehydic form of elenolic acid linked to either hydroxytyrosol (3,4-DHPEA-EDA; oleacein) or tyrosol (p-HPEA-EDA; oleocanthal), both existing as aglycones and glucosyl derivatives. Besides, VOO also contains phenolic alcohols such as tyrosol (p-HPEA) and hydroxytyrosol (3,4-DHPEA), mostly derived from their se-coiridoid precursors. The structures of these polyphenols are depicted in Figure 3. Other phenolic compounds also reported in lower amounts in VOO include lignans (pinoresinol, 1-acetoxypinoresinol, and 1-hydroxypinoresinol), verbascoside (i.e., caffeoylrhamnosyl-glucoside linked to hydroxytyrosol), some phenolic acids (vanillic, gallic, coumaric, caffeic acids) and flavonoids (especially flavonols derived from apigenin, luteolin, or quercetin) $[46,47]$.<smiles>Cc1cc(CCO)ccc1O</smiles>

Hydroxytyroso<smiles>OCCc1ccc(O)cc1</smiles>

Tyrosol<smiles>C/C=C(/C=O)C(CC=O)CC(=O)OCCc1ccc(O)cc1</smiles>

Oleocanthal<smiles>C/C=C1/C(O[C@H]2O[C@H](CO)[C@@H](O)[C@H](O)[C@H]2O)=CC=C(C(=O)OC)C1CC(=O)OCCc1ccc(O)c(O)c1</smiles>

Figure 3. Representative polyphenols present in virgin olive oils.

Olive oil phenolics have been extensively studied for their potential to counteract the onset and progression of a variety of chronic and aging-related diseases, and is attributed to hypoglycemic, anti-obesity, cardioprotective, neuroprotective, antimicrobial, and anti-cancer properties [47-49]. Several in vitro and in vivo studies have associated the health-promoting effects of olive oil phenolics to their antioxidant and anti-inflammatory potential as related to their ability to modulate a series of molecular pathways. Thus, they have been reported to be able to activate AMPK (AMP-activated protein kinase) with subsequent inhibition of the mTOR signaling pathway [22], which is involved in the regulation of adipose tissue functions, such as adipogenesis, thermogenesis, and lipid metabolism. It also modulates processes like mitochondrial biogenesis and functionality, hypoxia signaling, autophagy, and cell cycle progression [50]. In intervention studies, VOO-rich Mediterranean 
diets were deemed effective in reducing several inflammatory markers, such as C-reactive protein, TNF- $\alpha$, interleukin-6 (IL6), endothelial adhesion molecules (VCAM-1, ICAM), or chemokines like MCP-1, which has been related to their polyphenol content [40,51]. A compound that demonstrated strong in vitro anti-inflammatory properties is oleocanthal, with a structure that resembles ibuprofen, which was shown to cause a dose-dependent inhibition of cyclooxygenase enzymes COX-1 and COX-2 [52]. Similarly, hydroxytyrosol was able to inhibit TNF- $\alpha$, iNOS, and COX-2 in LPS-challenged human monocytic cell lines [53]. Additionally, in vitro and animal studies have reported that oleuropein and hydroxytyrosol may reduce fat tissue accumulation by downregulating the expression of adipogenesis-related genes like PGC- $1 \alpha$, lipoprotein lipase, acetyl CoA carboxylase- 1 , and carnitine palmitoyltransferase-1 [54]. Recent reviews can be consulted for further information on olive oil phenolic effects and mechanisms of action $[44,47,49,55,56]$.

The beneficial effects of phenolic compounds from olives and olive oil (i.e., hydroxytyrosol and oleuropein complex) were recognized by the European Food Safety Authority (EFSA), which authorized health claims in relation to polyphenols in olives and the protection of LDL particles from oxidative damage, the maintenance of normal blood HDL-cholesterol concentrations, the maintenance of normal blood pressure, and "antiinflammatory properties". It also recognized their contribution to upper respiratory tract health, body defences against external agents, and the maintenance of a normally functioning gastrointestinal tract [57].

Within the PREDIMED study (http:/ / www.predimed.es, accessed on 1 September 2021), a large Spanish trial on the primary prevention of chronic diseases through the Mediterranean Diet carried out in subjects at cardiovascular risk followed since 2013, it was estimated that olive oil and olives may provide about approximately $11 \%$ of the total polyphenol intake in a typical MedDiet, representing an important differential contribution to the profile of phenolic compounds consumed by Mediterranean populations [19]. Less optimistic calculations have been made by other authors. Thus, Parkinson and Cicerale [56], assuming a mean VOO intake of 30-50 g/day in Mediterranean countries, estimated that the amount of polyphenols ingested from VOO consumption would not exceed $9 \mathrm{mg} /$ day. Whatever the dietary intake, at present there is not enough evidence to confirm that the consumption of olive phenolic compounds isolated by or as components of the VOO can be healthy [58]. Most of the in vivo studies with olive oil polyphenols have been carried out using supraphysiological concentrations that are difficult to extrapolate to a dietary context, while the number and variety of randomized clinical trials (RCT) - providing the highest level of scientific evidence-are very limited and insufficient to confirm their beneficial effects on humans, except for some markers of cardiovascular risk. Actually, the strongest piece of evidence has been obtained for the ability of VOO polyphenols to protect lipoproteins from oxidation and to reduce systolic blood pressure in hypertensive individuals [56]. Extensive RCT in different population groups with distinct disorders and at phenolic levels adjusted to usual VOO consumptions are, therefore, necessary to achieve high quality scientific evidence before nutritional recommendations can be given [56,58].

The health benefits attributed to olive oil could also be supposed for table olives. Nevertheless, the phenolic composition of table olives differs from that of olive oil, as they are influenced not only by the cultivar and harvesting time (green or fully ripened), but also by the processing conditions used for making them edible, which lead to chemical transformations in the polyphenols $[59,60]$. Thus, under the alkaline conditions used for the debittering of fruits in Spanish-style olives, oleuropein is hydrolyzed to practical disappearance. Moreover, in Greek-style black olives, in which the fruits are collected fully ripened and directly put into brine, an acid hydrolysis of oleuropein occurs, and orthodiphenols are oxidized and polymerized during the darkening step [60]. Tyrosol and hydroxytyrosol and their acetates have been identified as the most representative phenolic compounds in table olives, with concentrations of total polyphenols ranging between $200 \mathrm{mg} / \mathrm{kg}$ to $1200 \mathrm{mg} / \mathrm{kg}$, depending on the cultivar and processing method, with oxidized olives containing the lowest levels. A further decrease of phenolic content 
is produced in pitted olives due to their loss in the washing liquids, which reduce their concentration to almost half that of the nonpitted fruits [60].

Besides polyphenols, olives also contain other bioactive compounds in the unsaponifiable fraction, such as pentacyclic triterpenoids like maslinic acid and oleanolic acid (Figure 4). A range of biological activities have been shown for maslinic acid, mostly from in vitro studies, such as anti-inflammatory, antiproliferative, antioxidant, and antidiabetic properties. In regard to oleanolic acid, hepatoprotective, antitumor, and antiviral properties have been reported [60-62]. These compounds are not lost during processing, and they are present in table olives and olive-pomace oil, a byproduct from olive oil extraction submitted to a refining process that leads to the complete loss of polyphenols. Table olives may contain more than $1300 \mathrm{mg} / \mathrm{kg}(\mathrm{dw})$ of maslinic acid, which is considered its richest food source [63]. Other dietary sources are spinach and eggplant, aromatic herbs, legumes, and to a lesser extent, some fruits like mandarin and pomegranate. Actually, plant-based diets including olives and olive oil, like the MedDiet, could provide a constant supply of maslinic acid, which might partly contribute to their health-enhancing properties [61].

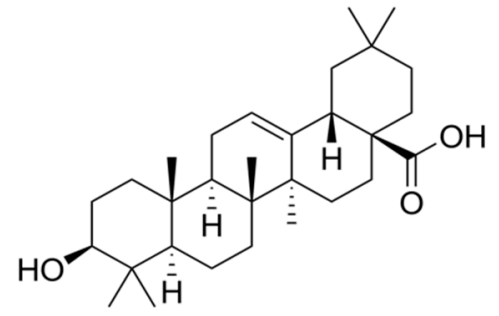

Oleanolic acid

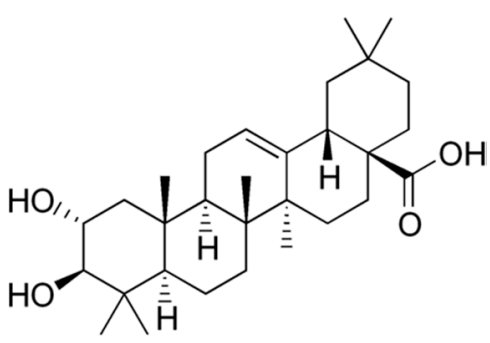

Maslinic acid

Figure 4. Structures of oleanolic and maslinic acids.

\section{Wine in the Context of the Mediterranean Diet}

Wine is considered another distinguishing food of the Mediterranean diet contributing to its health benefits [44]. Nevertheless, it should not be forgotten that in several countries and regions that follow typical Mediterranean dietary patterns, alcohol, and therefore wine, is excluded for religious reasons.

Since the early St. Leger et al. [64] and Framingham studies [65], a lot of epidemiological evidence has accumulated, pointing to the existence of inverse relationships between light to moderate alcohol consumption - especially wine-and incidences and mortality of cardiovascular diseases (see, e.g., [66-69]), as well as of other chronic disorders like type 2 diabetes [70-73] or dementia and cognitive decline in old age [74,75]. The relationship has been described as a U- or J-shaped curve [76], with a minimum situated at a level of consumption around 10 to $30 \mathrm{~g}$ of alcohol/day. These studies are not free from debate, as they have been attributed to suffer from methodological limitations, which may have led to misinterpretations or biased conclusions [77-80]. Nevertheless, despite possible bias, many authors agree that when confounding factors are specifically adjusted, epidemiological trials still continue to be remarkably consistent regarding the beneficial effects from low to moderate alcohol/wine intake on CVD morbidity and mortality, as well as diabetes, osteoporosis, and neurological disorders [81-83].

A point of discussion is whether the purported wine benefits are due to ethanol or to other components. It is known that ethanol itself is able to increase HDL-cholesterol, prevent platelet aggregation, and enhance fibrinolysis, which may have positive effects on the cardiovascular system [84]. However, when differentiation among drinks is made, it is generally concluded that wine provides superior health benefits to other alcoholic drinksespecially spirits-either regarding protection against CVD [85-88], type 2 diabetes [73], or dementia [89]. This perception has also been supported by the results obtained in human clinical studies [90-94] and observations over Mediterranean cohorts [19,39,95]. 
The intended superior benefits of wine have been related to its phenolic compounds, which are absent or in very low concentrations in other alcoholic drinks. Wine contains a variable mixture of flavonoid and non-flavonoid compounds, extracted from the grape during winemaking. Phenolic contents in red wine is usually well above $1 \mathrm{~g} / \mathrm{L}$-concentrations that are higher than those that can be found in most fruits and vegetables-while in white wine, it does not commonly exceed a few hundred $\mathrm{mg} / \mathrm{L}$, due to the fact that it is not normally submitted to maceration with grape solids during winemaking [96]. The majority phenolic fraction in red wine is constituted by flavonoids ( $>85 \%)$, especially procyanidins (i.e., flavan-3-ol oligo/polymers; condensed tannins). Actually, red wine is one of the richest dietary sources of procyanidins [97], a type of compound recognized to possess a range of biological activities, and that is related with the disease preventive properties of plant-based diets [98,99]. Red wine is also rich in anthocyanins (especially young red wine) and flavonols, with acknowledged biological activities, including antioxidant, anti-inflammatory, antiproliferative, or gene modulating abilities [100], which are also considered to contribute to the health protective effects of fruits and vegetables. Hydroxycinnamic acids and their tartaric esters are the most important phenolic compounds in white wine, while other phenolics, like hydroxybenzoic acids, stilbenes (e.g., resveratrol), lignans, or dihydroflavonols are usually present in low concentrations in either type of wine, usually not exceeding a few $\mathrm{mg} / \mathrm{L}$ [96].

Polyphenols, and especially flavonoids, have been proposed to be the main vasoactive components in red wine. They have been reported to be able to modulate the plasmatic lipid profile to a healthy shape, reducing triglyceride and LDL-cholesterol circulating levels $[90,101,102]$. They may also improve both systolic and diastolic blood pressure, stimulate endothelial-dependent vasodilation by enhancing nitric oxide (NO) generation, decrease platelet aggregation, and inhibit the activity of inflammatory enzymes and the production of several types of proinflammatory and oxidant mediators [103-105]. Many recent reports have been published dealing with the putative health effects of polyphenols, either from wine or other plant sources, and their possible mechanisms of action (see, e.g., $[17,106-111])$, and thus it does not seem necessary to insist herein.

In addition to polyphenols, other bioactive phenolic and non-phenolic components can also be present in wine that might contribute to the putative health effects and that are usually less considered. Thus, during must fermentation, yeasts catabolize aromatic amino acids - such as tyrosine, tryptophan, and phenylalanine - to their respective aromatic alcohols, tyrosol, tryptophol, and phenyl ethanol, which also possess bioactive properties and are also associated with some of the beneficial effects of moderate wine consumption [112]. Tyrosol has been indicated to be the second most abundant nonhydroxycinnamate phenolic in many wines, with concentrations that may reach up to $95 \mathrm{mg} / \mathrm{L}$. Its antioxidant and anti-inflammatory properties were suggested to contribute to the beneficial effects attributed to a moderate consumption of wine $[113,114]$. Among others, tyrosol was found to be able to inhibit the LPS-induced production of pro-inflammatory cytokines tumor necrosis, like factor alpha (TNF- $\alpha$ ), and interleukins IL-1 $\beta$ and IL-6 in human peripheral blood mononuclear cells at nanomolar concentrations, either alone or in synergy with caffeic acid $[113,114]$. Hydroxytyrosol is also present in wine in levels under $10 \mathrm{mg} / \mathrm{L}$ [115-117], but it can also be formed in the human organism from hydroxylation of tyrosol. De la Torre et al. [118] found that the consumption of moderate doses of wine or olive oil by healthy subjects led to a higher increase in urinary concentrations of hydroxytyrosol in the wine group, despite the fact that the amount of hydroxytyrosol administered was fivefold greater in the olive oil group $(1.7 \mathrm{mg}$ vs. $0.35 \mathrm{mg})$. This was explained by the biotransformation of tyrosol to hydroxytyrosol; besides, the alcohol could help to increase the bioavailability of the tyrosol present in the wine. The authors indicated that a single glass of wine was at least equivalent to $25 \mathrm{~mL}(22 \mathrm{~g})$ of virgin olive oil in its capacity to increase hydroxytyrosol concentrations in the body, leading to similar beneficial effects. The same group found that there was a direct association between wine consumption and the urinary concentrations of tyrosol and hydroxytyrosol determined in individuals at car- 
diovascular risk included in the PREDIMED study [119], suggesting that the endogenous formation of hydroxytyrosol might explain part of the cardiovascular benefits associated with light-to-moderate wine consumption.

Another bioactive compound that may contribute to the health benefits of wine is melatonin (n-acetyl-5-methoxytryptamine). This is a neurohormone secreted from the pineal gland, with well-characterized antioxidant, anti-inflammatory, and immune-modulating properties. It also contributes to the regulation of the circadian rhythms and has been attributed to tumor inhibitory activities and positive effects on the cardiovascular system, lipid, glucose metabolism, and neuroprotection [120,121]. It is present in grapes and can also be formed in wine from tryptophan metabolism by yeasts [122]. Actually, its content in wine is mostly influenced by the fermentation process, where the yeast strain and the fermentation time are the most influential factors [122]. It has been shown that blood levels of melatonin and total antioxidant capacity in plasma increased after the dietary intake of food containing it [123-125]. Melatonin concentrations ranging from a few $\mu \mathrm{g} / \mathrm{L}$ to more than $150 \mu \mathrm{g} / \mathrm{L}$ have been reported in wine [126], which is higher than those found in most fruits and vegetables. Moreover, most fruits and vegetables are usually situated in the low $\mathrm{ng} / \mathrm{g}$ level, with only a few products, such as mushrooms, coffee beans, or some berries showing contents in the $\mu \mathrm{g} / \mathrm{g}$ range [120]. Therefore, wine can be considered a significant source of dietary melatonin, though it is not unlikely that it could be a contributor to the beneficial effects associated with wine consumption [121].

\section{What about Resveratrol?}

A phenolic compound that has been frequently associated with the putative beneficial effects of wine is the stilbene resveratrol $\left(3,4^{\prime}, 5\right.$-trihydroxy-trans-stilbene), a phytoalexin that can be found in grape skin and is extracted into wine during winemaking. The average contents of resveratrol in wine does not usually exceed a few $\mathrm{mg} / \mathrm{L}$ [96]. Since white wine is not usually submitted to maceration with grape solids, it possesses lower resveratrol concentrations than red wine.

Dietary sources of resveratrol are scarce and, in addition to grapes, they include rhubarb, peanuts, or berries, though they are always present in low levels. Actually, grapes and wine are considered the most relevant food sources for humans [127]. Stilbenes are synthetized by plants in response to biotic or abiotic stress, so that exposure to UV radiation can induce the formation of resveratrol in grapes, increasing its concentration by up to tenfold [128]. Post-harvest UV irradiation has been employed as a strategy to increase resveratrol levels so as to "functionalize" grapes [129].

The presence of resveratrol in wine was firstly described in 1992 [130], suggesting that it might be an active component in the lowering effects of serum lipids associated with wine consumption. Since then, a high number of studies have been published reporting a diversity of bioactivities and multiple potential health outcomes for stilbene, including antioxidant, anti-inflammatory, anti-obesity, chemopreventive, glucose-modulating, cardiovascular protective, or calorie restriction mimicking effects [131]. A departure point in resveratrol research could be established in the study by Jang et al. [132], reporting its ability to inhibit the enzymatic activity of both forms of cyclooxygenase (COX1 and COX2), suggesting that it may behave as an anti-inflammatory and anticarcinogenic agent. Further studies showed that it was able to enhance stress resistance and extend lifespan in various model organisms, including Saccharomyces cerevisiae, Caenorhabditis elegans, Drosophila melanogaster, fish, and mice [133-135]. Those effects were related to the activation of Sir2 proteins (sirtuins), a family of $\mathrm{NAD}^{+}$-dependent deacetylases and mono-ADP-ribosyltransferases involved in key regulation processes, such as glucose and insulin production, fat metabolism, the regulation of the p53 tumour suppressor, and cell survival [136].

Later on, several authors have also explored the effects of resveratrol on obesity, brain function, and visual performance. The results obtained in a number of studies in cell, animal, and human trials revealed that resveratrol and related stilbenes were able to inhibit adipocyte differentiation and proliferation, decrease lipogenesis, and promote lipolysis 
and fatty acid beta-oxidation [137], pointing out that it may be used as an anti-obesity agent. Regarding brain function, Kennedy et al. [138] found that the oral administration of a single dose of resveratrol $(250 \mathrm{or} 500 \mathrm{mg}$ ) to healthy adults increased cerebral blood flow during task performance in a dose-dependent way without affecting cognitive function. Furthermore, Evans et al. [139] reported that daily consumption of $150 \mathrm{mg}$ of resveratrol for 14 weeks enhanced verbal memory and overall cognitive performance in postmenopausal women. Another study in postmenopausal women concluded that supplementation with $75 \mathrm{mg}$ of trans-resveratrol twice a day for a year improved overall cognitive performance and cerebrovascular responsiveness to cognitive stimuli, which was also associated with a reduction of fasting blood glucose [140]. By contrast, a nutritional intervention with $200 \mathrm{mg}$ /day of resveratrol failed to show significant improvements in verbal memory after 26 weeks in healthy elderly individuals [141]. Moreover, in a meta-analysis on the results obtained from four randomized clinical trials, Farzaei et al. [142] did not conclude significant effects on memory and cognitive performance assessed by auditory verbal learning test. Similarly, Marx et al. [143] concluded that, despite the fact that resveratrol supplementation might improve cognitive performance, the results obtained among clinical trials are limited and inconsistent. As for visual performance, studies carried out in different retinal cell lines found that resveratrol at micromolar concentrations was able to protect them from damage caused by oxidative stress and hyperglycemia-induced lowgrade inflammation, suggesting that it might contribute to preventing age-related ocular disorders like cataracts, glaucoma, or macular degeneration [144-146]. Additionally, oral administration of resveratrol ( 5 to $200 \mathrm{mg} / \mathrm{kg}$ for 5 days) to mice was seen to prevent endotoxin-induced uveitis by inhibiting oxidative damage, leading authors to propose that supplementation with resveratrol is a possible strategy to treat ocular inflammation [147].

However, despite the range of evidence on the potential benefits of resveratrol obtained in model and preclinical studies, attempts have failed to come to clear and consistent outcomes in cohort and clinical trials $[148,149]$. It must also be highlighted that the available studies have been performed using relatively high doses of resveratrol, which are unlikely to be provided by the diet when taking into account the scarcity of food sources and the very low concentrations at which stilbenes are present. It does not seem that Mediterranean diets, either with or without wine, can represent further improvements in this sense. Thus, it should not be expected that resveratrol may have a relevant contribution to the beneficial health effects associated with Mediterranean diets or any other type of diet. Supplementation or therapeutical approaches might, therefore, be the way to take advantage of its potential benefits. Nonetheless, much work seems still required in this respect. As recently reviewed by Ren et al. [148], poor pharmacokinetics and low potency - as well as possible toxicity issues, including gastrointestinal disorders, headache, rash, or nephrotoxicity $[131,148]$ — seem the main bottlenecks to overcome for its nutritional or therapeutical application. The development of more potent analogues and/or novel resveratrol formulations to enhance its bioavailability may be promising strategies to take it from bench to people [148].

\section{The Social Context}

Polyphenols are not the only reason that has been argued to support the beneficial effects associated with wine consumption, but socioeconomical and contextual factors also matter and could be even more important. Indeed, when interpreting the relationship between wine consumption and health, the underlying lifestyle and dietary patterns have to be considered, as they can be as influential on the health outcome as the type of drink. Mediterranean diets are themselves considered to constitute healthy dietary and lifestyle behaviour, making it difficult to extract the contribution of wine; otherwise, they might counteract the negative impact of alcohol on the organism.

It has been claimed that the MedDiet involves a "Mediterranean way of drinking", that is, a regular, moderate wine intake mainly consumed with meals [6]. When consumed with meals, wine tends to be sipped more slowly as compared to other alcoholic drinks, 
which may provide metabolic advantages. Among others, the concomitant presence of food in the stomach slows down gastric emptying and subsequent ethanol absorption which favours hepatic metabolism and clearance, lowering the peak of alcohol concentration in the blood [150]. It has been reported that, when consumed within meals, alcohol intake is associated with a lower risk of acute myocardial infarctions [151]. The concurrent presence of food might also reduce the amount of alcohol available to the oral microbiota, which has the capacity to metabolize ethanol to acetaldehyde, a compound associated with the tumorigenic effects of ethanol in the upper gastrointestinal tract [152]. It has also been observed that when wine is consumed with food, the onset of the plasma uric acid elevation coincides with the period of postprandial oxidative stress produced after a meal, which may contribute to the wine's protective effects [153]. Moreover, the presence of alcohol may improve the bioavailability of polyphenols in the food bolus, which would thus be more easily assimilated [154].

Studies in countries where wine is not the traditional alcoholic drink have also supported that a preference for wine is associated with healthy outcomes and more favourable dietary patterns [155]. Burke et al. [156], in a health screening on middle-aged men in Australia, found that a preference for wine was related to a greater consumption of fruit, vegetables, and bread, as compared to people that preferred beer. In a survey in Finland, Mannisto et al. [157] observed that wine drinkers had significantly higher intakes of antioxidants in their diet, indicating a greater consumption of fruit and vegetables than groups with other drink preferences. A higher intake of fruits, salads, cooked vegetables, fish, and olive oil was also found by Tjonneland et al. [158] in those that preferred wine, as compared with other alcoholic drinks, in a cross-sectional study conducted in Denmark. Similarly, Sluik et al. [159], in a representative sample of people from the Netherlands, found that wine drinkers consumed less energy and more vegetables and fruit juices, while the choice of beer was associated with a higher intake of meat, soft drinks, margarine, and snacks. All those behaviours associated with wine choice result in diets closer to the MedDiet, supporting the idea that it is not only wine, but the associated dietary and lifestyle patterns which contribute to healthier outcomes. Interestingly, this type of association has not been found in studies performed in some Mediterranean countries, as was the case of some Italian [160] or Spanish cohorts [161,162], where no significant correlation between wine consumption and healthier dietary habits was observed in relation to non-drinkers or consumers of other alcoholic beverages.

\section{Risks of Wine Consumption}

Despite the fact that moderate consumption may have health benefits, it is also wellknown that alcohol, even at a low level of consumption, has some risks. It is well-known that there is a causal relationship between alcohol intake and the incidence of a variety of pathologies-particularly liver diseases-which, in their more severe form, such as the alcoholic hepatitis, lead to a mortality rate exceeding 50\% in three months. Other manifestations, like steatosis of alcoholic cirrhosis, are initially less severe, although in advanced cirrhosis, the median of survival is situated around 1-2 years [163]. In addition, there are also well-established relationships between alcohol intake and incidence of pancreatitis and diverse types of cancer, as well as some infectious diseases and nonintentional injuries.

A comprehensive report on alcohol-attributable deaths was released in 2018 within the frame of the Global Burden of Diseases, Injuries, and Risk Factors Study 2016 [164]. For that, a meta-analysis of relative risks for 23 health outcomes associated with alcohol use was made using 694 data sources of individual and population-level alcohol consumption, along with 592 prospective and retrospective studies on the risk of alcohol use. The study used 195 locations and a time span from 1990 to 2016, including people aged above 15 of both sexes. It was concluded that alcohol use was a leading risk factor for the global disease burden worldwide, causing substantial health loss from many causes and accounting for nearly $10 \%$ of global deaths among people aged $15-49$ years. The risk of all-cause mortality, 
and of cancers specifically, raised with increasing levels of consumption, with no level of consumption that can be considered free of risks [164].

The International Agency for Research on Cancer (IARC) classifies alcohol as a Group 1 carcinogen, causally associated with the development of cancers of the upper digestive tract and liver, and has sufficient evidence to be positively associated with colorectum and female breast cancer, without differences among the type of alcoholic drink [165]. The existence of a high association between alcohol intake and the increased risk of different types of cancers was confirmed in many prospective studies. In a meta-analysis carried out on 156 epidemiological studies, Corrao et al. [166] concluded that the risk for all types of cancer significantly increased for ethanol intakes of above $25 \mathrm{~g} /$ day. Also, a highly significant association was found for liver cirrhosis and essential hypertension, although, for coronary heart disease and ischemic stroke, a reduction in the risk was observed with a minimum consumption of $20 \mathrm{~g}$ alcohol/day [66].

An aspect to notice is that observational studies on alcohol and health usually consider average alcohol consumption, which may hide risky drinking behaviours, such as irregular binge drinking, that always involves higher health risks and mortality rates $[167,168]$. A pattern of irregular heavy drinking is associated with pathophysiological mechanisms that increase the risk of sudden cardiac death, hypertension, atrial or ventricular fibrillation, and cardiomyopathy, even if the average consumption is comparable to moderate consumption [169]. Heavy drinking during pregnancy is known to produce foetal alcohol syndrome, leading to abnormalities and mental retardation. Nevertheless, there is also evidence that prenatal exposure to light to moderate levels of alcohol could affect foetal development and result in decreased body weight, neurodevelopmental deficits, and longterm effects on the growth of children $[170,171]$. All in all, there is no level of alcohol that can be considered safe during pregnancy. As a result, its consumption must be avoided by pregnant women, as well as during the period of breastfeeding. Similarly, alcohol must be avoided by younger people: adolescent alcohol use shows clear positive relationships with total mortality and is associated with an increased risk for development of chronic alcohol use disorders in adulthood [172].

It has been suggested that the detrimental effects of ethanol might be partly counterbalanced by the polyphenols contained in wine and other foods that play a part in the MedDiet, like extra-virgin olive oil [173], although this may be more of a perception that is not supported by consistent studies in humans. In a recent position paper on Dietary Guidelines for the Spanish Population [174], the Spanish Society of Community Nutrition (SENC) established that the consumption of alcoholic beverages is not encouraged or recommended in any case. Nevertheless, taking into account the prevalence of the Mediterranean uses and customs in Spain, an optional consumption of wine in limited amounts (no more than $40 \mathrm{~g}$ alcohol/day for men and no more than $20 \mathrm{~g}$ alcohol/day for women) and with meals is suggested only for adults who so desire and are not subject to contraindication due to a health condition or medication use. The SENC also highlighted that people who do not use alcoholic beverages should not start drinking because of its potential beneficial effects, and that equivalent results can be achieved through an adequate diet without the potential risks of alcohol.

\section{Concluding Remarks}

The Mediterranean diet has been associated with beneficial health outcomes in the prevention of chronic degenerative disorders, including cardiovascular diseases, type2 diabetes, cognitive decline, or cancers. Its benefits were recognized by the UNESCO, which in 2010 inscribed the Mediterranean diet as an Intangible Cultural Heritage of Humanity. A feature of the MedDiet that has been related to its health benefits is that it contributes significant amounts of antioxidants, and especially polyphenols, whose regular intake is related to beneficial effects on the lipids profile, blood pressure, glucose metabolism, adiposity, and inflammatory processes. Virgin olive oil and moderate wine consumption have been indicated as two distinctive hallmarks of the MedDiet, contributing 
to its health benefits [44]. Indeed, olive oil represents a differential Mediterranean product, with a peculiar phenolic composition based on secoiridoids and derived phenolic alcohols, described to be able to improve the blood lipidic profile, maintain blood pressure, and provide anti-inflammatory properties, as recognized by the EFSA with a health claim.

On the other hand, a moderate consumption of wine, especially red wine, has been proposed to provide some degree of protection against cardiovascular diseases, diabetes mellitus, or cognitive decline, which has been related to its polyphenol content. The available studies in this respect are, however, limited by their observational nature, and there is a lack of randomized clinical trials that may prove a causal relationship. Furthermore, wine contains alcohol, which even at moderate consumption increases the risks of liver disorders and several types of cancers, among other diseases, Although the Mediterranean habit of drinking wine with meals may delay ethanol absorption and favour its more rapid clearance, at the same time that it may contribute to a decrease in postprandial oxidative stress produced after a meal. Furthermore, although polyphenols present in wine are also found in fruits and vegetables that lack the risks associated with alcohol, the concomitant presence of ethanol in the food bolus might make wine polyphenols more bioavailable. Some authors have, however, highlighted that a high wine and total alcohol intake, particularly by men, can represent a problematic aspect of the Mediterranean diet that may have not been critically evaluated [175]. Indeed, the potential risks of wine consumption, even at moderate doses, may have been overlooked or undervalued by many authors, which inadvertently may have disclosed a confusing message, although not only restricted to the context of the Mediterranean diets. Certainly, it does not seem wise to think of wine or any other alcoholic drink as an element for health promotion, but the risks of alcohol should always be considered in the first place. Releasing any message that might induce people to drink in the hope of gaining health benefits could likely have more harmful than beneficial consequences.

All in all, it is not easy to give a simple answer to the question of whether wine should be considered a key food contributing to the beneficial health outcomes of the MedDiet. Despite the fact that it is excluded from the diet in many Mediterranean areas for religious reasons, we do think that it definitely constitutes a distinguishing feature of many Mediterranean cultures, and plays an undeniable part of their historical legacy. In those regions, wine can be a relevant contributor to polyphenol intake and could be considered a side element in the beneficial health effects of the MedDiet, provided that it is consumed in the 'traditional' way, that is, light to moderate regular consumption with meals. In our opinion, wine has to be regarded as a fruitive food, to be enjoyed responsibly and in moderation, in a convivial environment and in the context of an adequate diet. In this case, it may constitute another element of a healthy lifestyle, provided that there are no reasons that advise against their intake.

Author Contributions: Conceptualization, C.S.-B.; methodology, C.S.-B., S.G.-M. and A.M.G.-P.; resources, C.S.-B. and A.M.G.-P.; writing—original draft preparation, C.S.-B.; writing—review and editing, C.S.-B., S.G.-M. and A.M.G.-P.; project administration, C.S.-B. and A.M.G.-P.; funding acquisition, C.S.-B. and A.M.G.-P. All authors have read and agreed to the published version of the manuscript.

Funding: The GIP-USAL is funded by the Spanish Ministerio de Ciencia e Innovación (Project PID2019-106167RB-I00), Consejería de Educación de la Junta de Castilla y León (Project SA093P20), and Strategic Research Programs for Units of Excellence from Junta de Castilla y León (ref CLU-2018-04).

Conflicts of Interest: The authors declare no conflict of interest.

Sample Availability: Samples of the compounds are not available from the authors. 


\section{References}

1. Keys, A. Coronary heart disease in seven countries. Circulation 1970, 41, 186-195. [CrossRef]

2. Knoops, K.T.; de Groot, L.C.P.G.M.; Kromhout, D.; Perrin, A.E.; Moreiras-Varela, O.; Menotti, A.; van Staveren, W.A. Mediterranean diet; lifestyle factors; and 10-year mortality in elderly European men and women: The HALE project. JAMA 2004, 292, 1433-1439. [CrossRef]

3. Dinu, M.; Pagliai, G.; Casini, A.; Sofi, F. Mediterranean diet and multiple health outcomes: An umbrella review of meta-analyses of observational studies and randomised trials. Eur. J. Clin. Nutr. 2018, 72, 30-43. [CrossRef]

4. Serra-Majem, L.; Roman, B.; Estruch, R. Scientific evidence of interventions using the mediterranean diet: A systematic review. Nutr. Rev. 2006, 64, S27-S47. [CrossRef]

5. Davis, C.; Bryan, J.; Hodgson, J.; Murphy, K. Definition of the Mediterranean Diet: A Literature Review. Nutrients 2015, 7, 9139-9153. [CrossRef]

6. Giacosa, A.; Barale, R.; Bavaresco, L.; Faliva, M.A.; Gerbi, V.; La Vecchia, C.; Negri, E.; Opizzi, A.; Perna, S.; Pezzotti, M.; et al. Mediterranean way of drinking and longevity. Crit. Rev. Food Sci. Nutr. 2016, 56, 635-640. [CrossRef] [PubMed]

7. Román, G.C.; Jackson, R.E.; Gadhia, R.; Román, A.N.; Reis, J. Mediterranean diet: The role of long-chain $\omega$-3 fatty acids in fish; polyphenols in fruits; vegetables; cereals; coffee; tea; cacao and wine; probiotics and vitamins in prevention of stroke; age-related cognitive decline; and Alzheimer disease. Rev. Neurol. 2019, 175, 724-741. [CrossRef] [PubMed]

8. EFSA Panel on Dietetic Products; Nutrition and Allergies (NDA). Scientific Opinion on the substantiation of health claims related to oleic acid intended to replace saturated fatty acids (SFAs) in foods or diets and maintenance of normal blood LDL-cholesterol concentrations (ID 673; 728; 729; 1302; 4334) and maintenance of normal (fasting) blood concentrations of triglycerides (ID 673; 4334) pursuant to Article 13(1) of Regulation (EC) No 1924/2006. EFSA J. 2011, 9, 2043.

9. Saura-Calixto, F.; Goñi, I. Definition of the mediterranean diet based on bioactive compounds. Crit. Rev. Food Sci. Nutr. 2009, 49, 145-152. [CrossRef]

10. Grosso, G.; Buscemi, S.; Galvano, F.; Mistretta, A.; Marventano, S.; La Vela, V.; Drago, F.; Gangi, S.; Basile, F.; Biondi, A. Mediterranean diet and cancer: Epidemiological evidence and mechanism of selected aspects. BMC Surg. 2013, 13, 1-9. [CrossRef]

11. Mentella, M.C.; Scaldaferri, F.; Ricci, C.; Gasbarrini, A.; Miggiano, G.A.D. Cancer and Mediterranean Diet: A Review. Nutrients 2019, 11, 2059. [CrossRef] [PubMed]

12. Ruhee, R.T.; Suzuki, K. The Integrative role of sulforaphane in preventing inflammation; oxidative stress and fatigue: A review of a potential protective phytochemical. Antioxidants 2020, 9, 521. [CrossRef]

13. Cannataro, R.; Fazio, A.; La Torre, C.; Caroleo, M.C.; Cione, E. Polyphenols in the Mediterranean Diet: From Dietary Sources to microRNA Modulation. Antioxidants 2021, 10, 328. [CrossRef] [PubMed]

14. Chiva-Blanch, G.; Badimon, L. Effects of polyphenol intake on metabolic syndrome: Current evidences from human trials. Oxid. Med. Cell Longev. 2017, 2017, 5812401. [CrossRef]

15. Del Bo, C.; Bernardi, S.; Marino, M.; Porrini, M.; Tucci, M.; Guglielmetti, S.; Cherubini, A.; Carrieri, B.; Kirkup, B.; Kroon, P.; et al. Systematic review on polyphenol intake and health outcomes: Is there sufficient evidence to define a health-promoting polyphenol-rich dietary pattern? Nutrients 2019, 11, 1355.

16. Tresserra-Rimbau, A.; Rimm, E.B.; Medina-Remon, A.; Martínez-González, M.A.; de la Torre, R.; Corella, D.; Salas-Salvadó, J.; Gómez-Garcia, E.; Lapetra, J.; Arós, F.; et al. Inverse association between habitual polyphenol intake and incidence of cardiovascular events in the PREDIMED study. Nutr. Metab. Cardiovasc. Dis. 2014, 24, 639-647. [CrossRef]

17. Santos-Buelga, C.; González-Paramás, A.M.; Oludemi, T.; Ayuda-Durán, B.; González-Manzano, S. Plant phenolics as functional food ingredients. Adv. Food Nutr. Res. 2019, 90, 183-257.

18. Godos, J.; Marventano, S.; Mistretta, A.; Galvano, F.; Grosso, G. Dietary sources of polyphenols in the Mediterranean healthy Eating; Aging and Lifestyle (MEAL) study cohort. Int. J. Food Sci. Nutr. 2017, 68, 750-756. [CrossRef] [PubMed]

19. Tresserra-Rimbau, A.; Medina-Remón, A.; Pérez-Jiménez, J.; Martínez-González, M.A.; Covas, M.I.; Corella, D.; Salas-Salvadó, J.; Gómez-Gracia, E.; Lapetra, J.; Arós, F.; et al. Dietary intake and major food sources of polyphenols in a Spanish population at high cardiovascular risk: The PREDIMED study. Nutr. Metab. Cardiovasc. Dis. 2013, 23, 953-959. [CrossRef]

20. Vitale, M.; Masulli, M.; Rivellese, A.A.; Bonora, E.; Cappellini, F.; Nicolucci, A. Dietary intake and major food sources of polyphenols in people with type 2 diabetes: The TOSCA.IT Study. Eur. J. Nutr. 2018, 57, 679-688. [CrossRef] [PubMed]

21. Zamora-Ros, R.; Knaze, V.; Rothwell, J.A.; Hémon, B.; Moskal, A.; Overvad, K.; Tjønneland, A.; Kyrø, C.; Fagherazzi, G.; Boutron-Ruault, M.-C.; et al. Dietary polyphenol intake in Europe: The European Prospective Investigation into Cancer and Nutrition (EPIC) study. Eur. J. Nutr. 2016, 55, 1359-1375. [CrossRef]

22. Barrajón-Catalán, E.; Herranz-López, M.; Joven, J.; Segura-Carretero, A.; Alonso-Villaverde, C.; Menéndez, J.A.; Micol, V. Molecular promiscuity of plant polyphenols in the management of age-related diseases: Far beyond their antioxidant properties. Adv. Exp. Med. Biol. 2014, 824, 141-159.

23. Joven, J.; Micol, V.; Segura-Carretero, A.; Alonso-Villaverde, C.; Menéndez, J.A.; for the Bioactive Food Components Platform. Polyphenols and the modulation of gene expression pathways: Can we eat our way out of the danger of chronic disease? Crit. Rev. Food Sci. Nutr. 2014, 54, 985-1001. [CrossRef] [PubMed]

24. Aura, A.M. Microbial metabolism of dietary phenolic compounds in the colon. Phytochem. Rev. 2008, 7, 407-429. [CrossRef] 
25. Selma, M.V.; Espín, J.C.; Tomás-Barberán, F.A. Interaction between phenolics and gut microbiota: Role in human health. J. Agric. Food Chem. 2009, 57, 6485-6501. [CrossRef] [PubMed]

26. Karkovic Markovic, A.; Toric, J.; Barbaric, M.; Jakobušic Brala, C. Hydroxytyrosol, tyrosol and derivatives and their potential effects on human health. Molecules 2019, 24, 2001. [CrossRef] [PubMed]

27. González-Sarrías, A.; García-Villalba, R.; Romo-Vaquero, M.; Alasalvar, C.; Örem, A.; Zafrilla, P.; Tomás-Barberán, F.A.; Selma, M.V.; Espín, J.C. Clustering according to urolithin metabotype explains the interindividual variability in the improvement of cardiovascular risk biomarkers in overweight-obese individuals consuming pomegranate: A randomized clinical trial. Mol. Nutr. Food Res. 2017, 61, 1600830. [CrossRef] [PubMed]

28. Setchell, K.D.; Brown, N.M.; Lydeking-Olsen, E. The clinical importance of the metabolite equol-a clue to the effectiveness of soy and its isoflavones. J. Nutr. 2002, 132, 3577-3584. [CrossRef] [PubMed]

29. Adlercreutz, H. Lignans and human health. Crit. Rev. Clin. Lab. Sci. 2007, 44, 483-525. [CrossRef]

30. Etxeberria, U.; Arias, N.; Boqué, N.; Macarulla, M.T.; Portillo, M.P.; Martínez, J.A.; Milagro, F.I. Reshaping faecal gut microbiota composition by the intake of trans-resveratrol and quercetin in high-fat sucrose diet-fed rats. J. Nutr. Biochem. 2015, 26, 651-660. [CrossRef]

31. Jin, G.; Asou, Y.; Ishiyama, K.; Okawa, A.; Kanno, T.; Niwano, Y. Proanthocyanidin-rich grape seed extract modulates intestinal microbiota in ovariectomized mice. J. Food Sci. 2018, 83, 1149-1152. [CrossRef]

32. Cox, L.M.; Blaser, M.J. Pathways in microbe-induced obesity. Cell Metab. 2013, 17, 883-894. [CrossRef] [PubMed]

33. Cardona, F.; Andrés-Lacueva, C.; Tulipani, S.; Tinahones, F.J.; Queipo-Ortuño, M.I. Benefits of polyphenols on gut microbiota and implications in human health. J. Nutr. Biochem. 2013, 24, 1415-1422. [CrossRef]

34. Hervert-Hernández, D.; Pintado, C.; Rotger, R.; Goñi, I. Stimulatory role of grape pomace polyphenols on Lactobacillus acidophilus growth. Int. J. Food Microbiol. 2009, 136, 119-122. [CrossRef]

35. Pozuelo, M.J.; Agis-Torres, A.; Hervert-Hernández, D.; López-Oliva, M.E.; Muñoz-Martínez, E.; Rotger, R.; Goñi, I. Grape antioxidant dietary fiber stimulates Lactobacillus growth in rat cecum. J. Food Sci. 2012, 77, H59-H62. [CrossRef] [PubMed]

36. Fiesel, A.; Gessner, D.K.; Most, E.; Eder, K. Effects of dietary polyphenol-rich plant products from grape or hop on proinflammatory gene expression in the intestine; nutrient digestibility and faecal microbiota of weaned pigs. BMC Vet. Res. 2014, 10, 196. [CrossRef] [PubMed]

37. Kafantaris, I.; Kotsampasi, B.; Christodoulou, V.; Kokka, E.; Kouka, P.; Terzopoulou, Z.; Gerasopoulos, K.; Stagos, D.; Mitsagga, C.; Giavasis, I.; et al. Grape pomace improves antioxidant capacity and faecal microflora of lambs. J. Anim. Physiol. Anim. Nutr. 2017, 101, 108-121. [CrossRef]

38. Zorraquín, I.; Sánchez-Hernández, E.; Ayuda-Durán, B.; Silva, M.; González-Paramás, A.M.; Santos-Buelga, C.; Moreno-Arribas, M.V.; Bartolomé, B. Current and future experimental approaches in the study of grape and wine polyphenols interacting gut microbiota. J. Sci. Food Agric. 2020, 100, 3789-3802. [CrossRef] [PubMed]

39. Zamora-Ros, R.; Serafini, M.; Estruch, R.; Lamuela-Raventós, R.M.; Martínez-González, M.A.; Salas-Salvadó, J.; Fiol, M.; Lapetra, J.; Arós, F.; Covas, M.I.; et al. Mediterranean diet and non-enzymatic antioxidant capacity in the PREDIMED study: Evidence for a mechanism of antioxidant tuning. Nutr. Metab. Cardiovasc. Dise. 2013, 23, 1167-1174. [CrossRef] [PubMed]

40. Medina-Remón, A.; Casas, R.; Tressserra-Rimbau, A.; Ros, E.; Martínez-González, M.A.; Fitó, M.; Corella, D.; Salas-Salvadó, J.; Lamuela-Raventós, R.M.; Estruch, R.; et al. Polyphenol intake from a Mediterranean diet decreases inflammatory biomarkers related to atherosclerosis: A substudy of the PREDIMED trial. Br. J. Clin. Pharmacol. 2017, 83, 114-128. [CrossRef]

41. Covas, M.I.; de la Torre, R.; Fitó, M. Virgin olive oil: A key food for cardiovascular risk protection. Br. J. Nutr. 2015, 113, S19-S28. [CrossRef]

42. Mata, P.; Garrido, J.A.; Ordovás, J.M.; Blázquez, E.; Alvarez-Sala, L.A.; Rubio, M.J.; Alonso, R.; de Oya, M. Effect of dietary monounsaturated fatty acids on plasma lipoproteins and apolipoproteins in women. Am. J. Clin. Nutr. 1992, 56, 77-83. [CrossRef]

43. Smith, R.D.; Kelly, C.N.M.; Fielding, B.A.; Hauton, D.; Silva, K.D.R.R.; Nydahl, M.C.; Miller, G.J.; Williams, C.M. Long-term monounsaturated fatty acid diets reduce platelet aggregation in healthy young subjects. Br. J. Nutr. 2007, 90, 597-606. [CrossRef]

44. Ditano-Vázquez, P.; Torres-Peña, J.D.; Galeano-Valle, F.; Pérez-Caballero, A.I.; Demelo-Rodríguez, P.; López-Miranda, J.; Katsiki, N.; Delgado-Lista, J.; Alvarez-Sala-Walther, L.A. The fluid aspect of the Mediterranean diet in the prevention and management of cardiovascular disease and diabetes: The role of polyphenol content in moderate consumption of wine and olive oil. Nutrients 2019, 11, 2833. [CrossRef]

45. Ramírez-Tortosa, M.C.; Granados, S.; Quiles, J.L. Chemical composition; types and characteristics of olive oil. In Olive Oil Health; CABI Publishing: Oxford, UK, 2006; pp. 45-61.

46. Servili, M.; Esposto, S.; Fabiani, R.; Urbani, S.; Taticchi, A.; Mariucci, F.; Selvaggini, R.; Montedoro, G.F. Phenolic compounds in olive oil: Antioxidant, health and organoleptic activities according to their chemical structure. Inflammopharmacology 2009, 17, 76-84. [CrossRef] [PubMed]

47. Rodríguez-López, P.; Lozano-Sánchez, J.; Borrás-Linares, I.; Emanuelli, T.; Menéndez, J.A.; Segura-Carretero, A. Structurebiological activity relationships of extra-virgin olive oil phenolic compounds: Health properties and bioavailability. Antioxidants 2020, 9, 685. [CrossRef] [PubMed]

48. Covas, M.I.; Nyyssonen, K.; Poulsen, H.E.; Kaikkonen, J.; Zunft, H.J.; Kiesewetter, H.; Gaddi, A.; de la Torre, R.; Mursu, J.; Bäumler, H.; et al. The effect of polyphenols in olive oil on heart disease risk factors: A randomized trial. Ann. Intern. Med. 2006, 145, 333-341. [CrossRef] [PubMed] 
49. Bucciantini, M.; Leri, M.; Nardiello, P.; Casamenti, F.; Stefani, M. Olive Polyphenols: Antioxidant and anti-inflammatory properties. Antioxidants 2021, 10, 1044. [CrossRef]

50. Cai, Y.; Yang, L.; Hu, G.; Chen, X.; Niu, F.; Yuan, L.; Liu, H.; Xiong, H.; Arikkath, J.; Buch, S. Regulation of morphine-induced synaptic alterations: Role of oxidative stress, ER stress, and autophagy. J. Cell Biol. 2016, 215, 245-258. [CrossRef]

51. Urpi-Sardá, M.; Casas, R.; Chiva-Blanch, G.; Romero-Mamani, E.S.; Valderas-Martínez, P.; Arranz, S.; Andrés-Lacueva, C.; Llorach, R.; Medina-Remón, A.; Lamuela-Raventós, R.M.; et al. Virgin olive oil and nuts as key foods of the Mediterranean diet effects on inflammatory biomarkers related to atherosclerosis. Pharmacol. Res. 2012, 65, 577-583. [CrossRef]

52. Beauchamp, G.K.; Keast, R.S.; Morel, D.; Lin, J.; Pika, J.; Han, Q.; Lee, C.H.; Smith, A.B.; Breslin, P.A. Phytochemistry: Ibuprofenlike activity in extra-virgin olive oil. Nature 2005, 437, 45-46. [CrossRef]

53. Zhang, X.; Cao, J.; Zhong, L. Hydroxytyrosol inhibits proinflammatory cytokines, iNOS, and COX-2 expression in human monocytic cells. Naunyn-Schmiedeberg's Arch. Pharmacol. 2009, 379, 581-586. [CrossRef]

54. Finicelli, M.; Squillaro, T.; Di Cristo, F.; Di Salle, A.; Beatrice Melone, M.A.; Galderisi, U.; Peluso, G. Metabolic syndrome, Mediterranean diet, and polyphenols: Evidence and perspectives. J. Cell. Physiol. 2019, 234, 5807-5826. [CrossRef]

55. Emma, M.R.; Augello, G.; Di Stefano, V.; Azzolina, A.; Giannitrapani, L.; Montalto, G.; Cervello, M.; Cusimano, A. Potential uses of olive oil secoiridoids for the prevention and treatment of cancer: A narrative review of preclinical studies. Int. J. Mol. Sci. 2021, 22, 1234. [CrossRef] [PubMed]

56. Parkinson, L.; Cicerale, S. The health benefiting mechanisms of virgin olive oil phenolic compounds. Molecules 2016, 16,1734 . [CrossRef] [PubMed]

57. EFSA Panel on Dietetic Products; Nutrition and Allergies (NDA). Scientific Opinion on the substantiation of health claims related to polyphenols in olive and protection of LDL particles from oxidative damage (ID 1333; 1638; 1639; 1696; 2865); maintenance of normal blood HDL-cholesterol concentrations (ID 1639); maintenance of normal blood pressure (ID 3781); "anti-inflammatory properties" (ID 1882); “contributes to the upper respiratory tract health" (ID 3468); "can help to maintain a normal function of gastrointestinal tract" (3779); and "contributes to body defences against external agents" (ID 3467) pursuant to Article 13(1) of Regulation (EC) No 1924/2006. EFSA J. 2011, 9, 203.

58. Castellano, J.M.; Perona, J.S. Effects of virgin olive oil phenolic compounds on health: Solid evidence or just another fiasco? Grasas Y Aceites 2021, 72, e404. [CrossRef]

59. Romero, C.; Brenes, M.; Yousfi, K.; García, P.; García, A.; Garrido, A. Effect of cultivar and processing method on the contents of polyphenols in table olives. J. Agric. Food Chem. 2004, 52, 479-484. [CrossRef] [PubMed]

60. Juan, M.E.; Planas, J.M.; Ruiz-Gutierrez, V.; Daniel, H.; Wenzel, U. Antiproliferative and apoptosis-inducing effects of maslinic and oleanolic acids, two pentacyclic triterpenes from olives, on HT-29 colon cancer cells. Br. J. Nutr. 2008, 100, 36-43. [CrossRef]

61. Lozano-Mena, G.; Sánchez-González, M.; Juan, M.E.; Planas, J.M. Maslinic acid, a natural phytoalexin-type triterpene from olives. A promising nutraceutical? Molecules 2014, 19, 11538-11559. [CrossRef]

62. Nagai, N.; Yagyu, S.; Hata, A.; Nirengi, S.; Kotani, K.; Moritani, T.; Sakane, N. Maslinic acid derived from olive fruit in combination with resistance training improves muscle mass and mobility functions in the elderly. J. Clin. Biochem. Nutr. 2019, 64, 224-230. [CrossRef]

63. Romero, C.; García, A.; Medina, E.; Ruiz-Méndez, M.V.; de Castro, A.; Brenes, M. Triterpenic acids in table olives. Food Chem. 2010, 118, 670-674. [CrossRef]

64. St Leger, A.S.; Cochrane, A.L.; Moore, F. Factors associated with cardiac mortality in developed countries with particular reference to the consumption of wine. Lancet 1979, 313, 1017-1020. [CrossRef]

65. Gordon, T.; Kannell, W.B. Drinking habits and cardiovascular disease: The Framingham study. Am. Heart J. 1983, 105, 667-673. [CrossRef]

66. Corrao, G.; Rubbiati, L.; Bagnardi, V.; Zambon, A.; Poikolainen, K. Alcohol and coronary heart disease: A meta-analysis. Addiction 2000, 95, 1505-1523. [CrossRef] [PubMed]

67. Di Castelnuovo, A.; Costanzo, S.; Bagnardi, V.; Donati, M.B.; Iacoviello, L.; de Gaetano, G. Alcohol dosing and total mortality in men and women: An updated meta-analysis of 34 prospective studies. Arch. Intern. Med. 2006, 166, 2437-2445. [CrossRef] [PubMed]

68. Larsson, S.C.; Wallin, A.; Wolk, A. Alcohol consumption and risk of heart failure: Metaanalysis of 13 prospective studies. Clin. Nutr. 2018, 37, 1247-1251. [CrossRef]

69. Reynolds, K.; Lewis, B.; Nolen, J.D.; Kinney, G.L.; Sathya, B.; He, J. Alcohol consumption and risk of stroke: A meta-analysis. JAMA 2003, 289, 579-588. [CrossRef] [PubMed]

70. Carlsson, S.; Hammar, N.; Grill, V. Alcohol consumption and type 2 diabetes Metaanalysis of epidemiological studies indicates a U-shaped relationship. Diabetologia 2005, 48, 1051-1054. [CrossRef] [PubMed]

71. Koppes, L.L.J.; Dekker, J.M.; Hendriks, H.F.J.; Bouter, L.M.; Heine, R.J. Moderate alcohol consumption lowers the risk of type 2 diabetes: A meta-analysis of prospective observational studies. Diabetes Care 2005, 28, 719-725. [CrossRef] [PubMed]

72. Djousse, L.; Biggs, M.L.; Mukamal, K.J.; Siscovick, D.S. Alcohol consumption and type 2 Diabetes among older adults: The Cardiovascular Health Study. Obesity 2007, 15, 1758-1765. [CrossRef]

73. Huang, J.; Wang, X.; Zhang, Y. Specific types of alcoholic beverage consumption and risk of type 2 diabetes: A systematic review and meta-analysis. J. Diabetes Invest. 2017, 8, 56-68. [CrossRef] 
74. Letenneur, L. Risk of dementia and alcohol and wine consumption: A review of recent results. Biol. Res. 2004, 37, 189-193. [CrossRef]

75. Peters, R.; Peters, J.; Warner, J.; Beckett, N.; Bulpitt, C. Alcohol, dementia and cognitive decline in the elderly: A systematic review. Age Ageing 2008, 37, 505-512. [CrossRef]

76. Marmot, M.G.; Shipley, M.J.; Rose, G.; Thomas, B. Alcohol and mortality: A U-shaped curve. Lancet 1981, 315, 580-583. [CrossRef]

77. Fillmore, K.; Stockwell, T.; Chikritzhs, T.; Bostrom, A.; Kerr, W. Moderate alcohol use and reduced mortality risk: Systematic error studies and new hypotheses. Ann. Epidemiol. 2007, 17, 16-23. [CrossRef] [PubMed]

78. Roerecke, M.; Rehm, J. Alcohol consumption, drinking patterns, and ischemic heart disease: A narrative review of meta-analyses and a systematic review and meta-analysis of the impact of heavy drinking occasions on risk for moderate drinkers. BMC Med. 2014, 12, 1-11. [CrossRef]

79. Naimi, T.S.; Stockwell, T.; Zhao, J.; Xuan, Z.; Dangardt, F.; Saitz, R.; Liang, W.; Chikritzhs, T. Selection biases in observational studies affect associations between 'moderate' alcohol consumption and mortality. Addiction 2017, 112, 207-214. [CrossRef]

80. Naimi, T.S.; Stadtmueller, L.A.; Chikritzhs, T.; Stockwell, T.; Zhao, J.; Britton, A.; Saitz, R.; Sherk, A. Alcohol, age, and mortality: Estimating selection bias due to premature death. J. Stud. Alcohol Drugs 2019, 80, 63-68. [CrossRef] [PubMed]

81. Hansel, B.; Thomas, F.; Pannier, B.; Bean, K.; Kontush, A.; Chapman, M.J.; Bruckert, E. Relationship between alcohol intake, health and social status and cardiovascular risk factors in the urban Paris-Ile-De-France Cohort: Is the cardioprotective action of alcohol a myth. Eur. J. Clin. Nutr. 2010, 64, 561-568. [CrossRef] [PubMed]

82. Rehm, J.; Roerecke, M. Cardiovascular effects of alcohol consumption. Trends Cardiov. Med. 2017, 27, 534-538. [CrossRef]

83. Zhao, J.; Stockwell, T.; Roemer, A.; Naimi, T.; Chikritzhs, T. Alcohol consumption and mortality from coronary heart disease: An updated meta-analysis of cohort studies. J. Stud. Alcohol Drugs 2017, 78, 375-386. [CrossRef] [PubMed]

84. Covas, M.I.; Gambert, P.; Fitó, M.; de la Torre, R. Wine and oxidative stress: Up-to-date evidence of the effects of moderate wine consumption on oxidative damage in humans. Atherosclerosis 2010, 208, 297-304. [CrossRef] [PubMed]

85. Gronbaek, M.; Deis, A.; Sorensen, T.I.A.; Becker, U.; Schnohr, P.; Jensen, G. Mortality associated with moderate intakes of wine, beer, or spirits. BMJ 1995, 310, 1165-1169. [CrossRef]

86. Haseeb, S.; Alexander, B.; Baranchuk, A. Wine and Cardiovascular Health. Circulation 2017, 136, 1434-1448. [CrossRef]

87. Liberale, L.; Bonaventura, A.; Montecucco, F.; Dallegri, F.; Carbone, F. Impact of red wine consumption on cardiovascular health Cur. Med. Chem. 2019, 26, 3542-3566. [CrossRef]

88. Snopek, L.; Mlcek, J.; Sochorova, L.; Baron, M.; Hlavacova, I.; Jurikova, T.; Kizek, R.; Sedlackova, E.; Sochor, J. Contribution of red wine consumption to human health protection. Molecules 2018, 23, 1684. [CrossRef] [PubMed]

89. Pinder, R.M.; Sandler, M. Alcohol, wine and mental health: Focus on dementia and stroke. J. Psychopharm. 2004, 18, 449-456. [CrossRef]

90. Chiva-Blanch, G.; Urpi-Sardá, M.; Ros, E.; Valderas-Martínez, P.; Casas, R.; Arranz, S.; Guillén, M.; Lamuela-Raventós, R.M.; Llorach, R.; Andrés-Lacueva, C.; et al. Effects of red wine polyphenols and alcohol on glucose metabolism and the lipid profile: A randomized clinical trial. Clin. Nutr. 2013, 32, 200-206. [CrossRef]

91. Droste, D.W.; Iliescu, C.; Vaillant, M.; Gantenbein, M.; De Bremaeker, N.; Lieunard, C.; Velez, T.; Meyer, M.; Guth, T.; Kuemmerle, A.; et al. A daily glass of red wine associated with lifestyle changes independently improves blood lipids in patients with carotid arteriosclerosis: Results from a randomized controlled trial. Nutr. J. 2013, 12, 147. [CrossRef]

92. Estruch, R.; Sacanella, E.; Mota, F.; Chiva-Blanch, G.; Antúnez, E.; Casals, E.; Urbano-Marquez, A. Moderate consumption of red wine, but not gin, decreases erythrocyte superoxide dismutase activity: A randomised cross-over trial. Nutr. Metab. Cardiovasc. Dis. 2011, 21, 46-53. [CrossRef]

93. Toth, A.; Sandor, B.; Papp, J.; Rabai, M.; Botor, D.; Horvath, Z.; Kenyeres, P.; Juricskay, I.; Toth, K.; Czopf, L. Moderate red wine consumption improves hemorheological parameters in healthy volunteers. Clin. Hemorheol, Microc. 2014, 56, 13-23. [CrossRef] [PubMed]

94. Vázquez-Fresno, R.; Llorach, R.; Perera, A.; Mandal, R.; Feliz, M.; Tinahones, F.J.; Wishart, D.S.; Andrés-Lacueva, C. Clinical phenotype clustering in cardiovascular risk patients for the identification of responsive metabotypes after red wine polyphenol intake. J. Nutr. Biochem. 2016, 28, 14-20. [CrossRef]

95. Gea, A.; Bes-Rastrollo, M.; Toledo, E.; García-López, M.; Beunza, J.J.; Estruch, R.; Martinez-Gonzalez, M.A. Mediterranean alcohol-drinking pattern and mortality in the SUN (Seguimiento Universidad de Navarra) Project: A prospective cohort study. Br. J. Nutr. 2014, 111, 1871-1880. [CrossRef] [PubMed]

96. Waterhouse, A.L. Wine phenolics. Ann. N. Y. Acad. Sci. 2002, 957, 21-36. [CrossRef] [PubMed]

97. Manach, C.; Scalbert, A.; Morand, C.; Rémésy, C.; Jiménez, L. Polyphenols: Food sources and bioavailability. Am. J. Clin. Nutr. 2004, 79, 727-747. [CrossRef]

98. Rasmussen, S.E.; Frederiksen, H.; Krogholm, K.S.; Poulsen, L. Dietary proanthocyanidins: Occurrence, dietary intake, bioavailability, and protection against cardiovascular disease. Mol. Nutr. Food Res. 2005, 49, 159-174. [CrossRef]

99. Santos-Buelga, C.; Scalbert, A. Proanthocyanidins and tannin-like compounds-Nature, occurrence, dietary intake and effects on nutrition and health. J. Sci. Food Agric. 2000, 80, 1094-1117. [CrossRef]

100. Santos-Buelga, C.; González-Paramás, A.M. Flavonoids: Functions, metabolism and biotechnology. In Industrial Biotechnology of Vitamins, Pigments, and Antioxidants; John Wiley \& Sons, Inc.: Weinhein, Germany, 2016; pp. 469-496. 
101. Frankel, E.; Kanner, J.; German, J.; Parks, E.; Kinsella, J. Inhibition of oxidation of human low-density lipoprotein by phenolic substances in red wine. Lancet 1993, 341, 454-457. [CrossRef]

102. Rifler, J.-P.; Lorcerie, F.; Durand, P.; Delmas, D.; Ragot, K.; Limagne, E.; Mazué, F.; Riedinger, J.-M.; d'Athis, P.; Hudelot, B. A moderate red wine intake improves blood lipid parameters and erythrocytes membrane fluidity in post myocardial infarct patients. Mol. Nutr. Food Res. 2012, 56, 345-351. [CrossRef] [PubMed]

103. Araim, O.; Ballantyne, J.; Waterhouse, A.L.; Sumpio, B.E. Inhibition of vascular smooth muscle cell proliferation with red wine and red wine polyphenols. J. Vasc. Surg. 2002, 35, 1226-1232. [CrossRef]

104. Diebolt, M.; Bucher, B.; Andriantsitohaina, R. Wine polyphenols decrease blood pressure, improve NO vasodilatation, and induce gene expression. Hypertension 2001, 38, 159-165. [CrossRef]

105. Zenebe, W.; Pechanova, O.; Andriantsitohaina, R. Red wine polyphenols induce vasorelaxation by increased nitric oxide bioactivity. Physiol. Res. 2003, 52, 425-432. [PubMed]

106. Del Rio, D.; Rodríguez-Mateos, A.; Spencer, J.P.; Tognolini, M.; Borges, G.; Crozier, A. Dietary (poly) phenolics in human health: Structures, bioavailability, and evidence of protective effects against chronic diseases. Antiox. Redox Signal. 2013, 18, 1818-1892 [CrossRef]

107. Cueva, C.; Gil-Sánchez, I.; Ayuda-Durán, B.; González-Manzano, S.; González-Paramás, A.M.; Santos-Buelga, C.; Bartolomé, B.; Moreno-Arribas, M.V. An integrated view of the effects of wine polyphenols and their relevant metabolites on gut and host health. Molecules 2017, 22, 99. [CrossRef]

108. Fernandes, I.; Pérez-Gregorio, R.; Soares, S.; Mateus, N.; de Freitas, V. Wine Flavonoids in health and disease prevention. Molecules 2017, 22, 292. [CrossRef] [PubMed]

109. Williamson, G.; Kay, C.D.; Crozier, A. The bioavailability, transport, and bioactivity of dietary flavonoids: A review from a historical perspective. Comp. Rev. Food Sci. Food Saf. 2018, 17, 1054-1112. [CrossRef] [PubMed]

110. Fraga, C.G.; Croft, K.D.; Kennedy, D.O.; Tomás-Barberán, F.A. The effects of polyphenols and other bioactives on human health Food Funct. 2019, 10, 514. [CrossRef]

111. González-Paramás, A.M.; Ayuda-Durán, B.; Martínez, S.; González-Manzano, S.; Santos-Buelga, C. The Mechanisms behind the Biological Activity of Flavonoids. Cur. Med. Chem. 2019, 26, 6976-6990. [CrossRef] [PubMed]

112. Mas, A.; Guillamón, J.M.; Torija, M.J.; Beltrán, G.; Cerezo, A.B.; Troncoso, A.M.; García-Parrilla, M.C. Bioactive compounds derived from the yeast metabolism of aromatic amino acids during alcoholic fermentation. BioMed Res. Int. 2014, 2014. [CrossRef]

113. Bertelli, A.A.E.; Migliori, M.; Panichi, V.; Longoni, B.; Origlia, N.; Ferretti, A.; Cuttano, M.G.; Giovannini, L. Oxidative stress and inflammatory reaction modulation by white wine. Ann. N. Y. Acad. Sci. 2002, 957, 295-301. [CrossRef] [PubMed]

114. Bertelli, A.; Migliori, M.; Bertelli, A.A.E.; Origlia, N.; Filippi, C.; Panichi, V.; Falchi, M.; Giovannini, L. Effect of some white wine phenols in preventing inflammatory cytokine release. Drugs Exp. Clin. Res. 2002, 28, 11-15.

115. Bordiga, M.; Lorenzo, C.; Pardo, F.; Salinas, M.R.; Travaglia, F.; Arlorio, M.; Garde-Cerdán, T. Factors influencing the formation of histaminol, hydroxytyrosol, tyrosol, and tryptophol in wine: Temperature; alcoholic degree, and amino acids concentration. Food Chem. 2016, 197, 1038-1045. [CrossRef] [PubMed]

116. Piñeiro, Z.; Cantos-Villar, E.; Palma, M.; Puertas, B. Direct liquid chromatography method for the simultaneous quantification of hydroxytyrosol and tyrosol in red wines. J. Agric. Food Chem. 2011, 59, 11683-11689. [CrossRef] [PubMed]

117. Rocchetti, G.; Gatti, M.; Bavaresco, L.; Lucini, L. Untargeted metabolomics to investigate the phenolic composition of Chardonnay wines from different origins. J. Food Comp. Anal. 2018, 71, 87-93. [CrossRef]

118. De La Torre, R.; Covas, M.I.; Pujadas, M.A.; Fitó, M.; Farré, M. Is dopamine behind the health benefits of red wine? Eur. J. Nutr. 2006, 45, 307-310. [CrossRef]

119. Pérez-Mañá, C.; Farré, M.; Rodríguez-Morató, J.; Papaseit, E.; Pujadas, M.; Fitó, M.; Robledo, P.; Covas, M.I.; Cheynier, V.; Meudec, E.; et al. Moderate consumption of wine, through both its phenolic compounds and alcohol content, promotes hydroxytyrosol endogenous generation in humans. A randomized controlled trial. Mol. Nutr. Food Res. 2015, 59, 1213-1216. [CrossRef]

120. Meng, X.; Li, Y.; Li, S.; Zhou, Y.; Gan, R.Y.; Xu, D.P.; Li, H.B. Dietary sources and bioactivities of melatonin. Nutrients 2017, 9, 367. [CrossRef]

121. Iriti, M.; Varoni, E.M. Cardioprotective effects of moderate red wine consumption: Polyphenols vs ethanol. J. Appl. Biomed. 2014, 12, 193-202. [CrossRef]

122. Fernández-Cruz, E.; Cerezo, A.B.; Cantos-Villar, E.; Troncoso, A.M.; García-Parrilla, M.C. Time course of l-tryptophan metabolites when fermenting natural grape musts: Effect of inoculation treatments and cultivar on the occurrence of melatonin and related indolic compounds. Aust. J. Grape Wine Res. 2019, 25, 92-100. [CrossRef]

123. Aguilera, Y.; Rebollo-Hernanz, M.; Herrera, T.; Cayuelas, L.T.; Rodríguez-Rodríguez, P.; de Pablo, Á.L.; Arribas, S.M.; MartinCabrejas, M.A. Intake of bean sprouts influences melatonin and antioxidant capacity biomarker levels in rats. Food Funct. 2016, 7, 1438-1445. [CrossRef]

124. González-Flores, D.; Gamero, E.; Garrido, M.; Ramírez, R.; Moreno, D.; Delgado, J.; Valdés, E.; Barriga, C.; Rodríguez, A.B.; Paredes, S.D. Urinary 6-sulfatoxymelatonin and total antioxidant capacity increase after the intake of a grape juice cv. Tempranillo stabilized with HHP. Food Funct. 2012, 3, 34-39. [CrossRef]

125. Reiter, R.J.; Manchester, L.C.; Tan, D.X. Melatonin in walnuts: Influence on levels of melatonin and total antioxidant capacity of blood. Nutrition 2003, 21, 579-588. [CrossRef] [PubMed] 
126. Rodríguez-Naranjo, M.I.; Torija, M.J.; Mas, A.; Cantos-Villar, E.; García-Parrilla, M.C. Production of melatonin by Saccharomyces strains undergrowth and fermentation conditions. J. Pineal Res. 2012, 53, 219-224. [CrossRef]

127. Benbouguerra, N.; Hornedo-Ortega, R.; Garcia, F.; El Khawand, T.; Saucier, C.; Richard, T. Stilbenes in grape berries and wine and their potential role as anti-obesity agents: A review. Trends Food Sci. Technol. 2021, 112, 362-381. [CrossRef]

128. Triska, J.; Houska, M. Physical methods of resveratrol induction in grapes and grape products-A review. Czech J. Food Sci. 2012, 30, 489-502. [CrossRef]

129. Cantos, E.; Espín, J.C.; Tomás-Barberán, F.A. Postharvest induction modeling method using UV irradiation pulses for obtaining resveratrol-enriched table grapes: A new "functional" fruit? J. Agric. Food Chem. 2001, 49, 5052-5058. [CrossRef] [PubMed]

130. Siemann, E.H.; Creasy, L.L. Concentration of the phytoalexin resveratrol in wine. Am. J. Enol. Vitic. 1992, 43, 49-52.

131. Cottart, C.H.; Nivet-Antoine, V.; Beaudeux, J.L. Review of recent data on the metabolism, biological effects, and toxicity of resveratrol in humans. Mol. Nutr. Food Res. 2014, 58, 7-21. [CrossRef]

132. Jang, M.; Cai, L.; Udeani, G.O.; Slowing, K.V.; Thomas, C.F.; Beecher, C.W.; Fong, H.H.; Farnsworth, N.R.; Kinghorn, A.D.; Mehta, R.G.; et al. Cancer chemopreventive activity of resveratrol; A natural product derived from grapes. Science 1997, 275, 218-220. [CrossRef]

133. Baur, J.A.; Pearson, K.J.; Price, N.L.; Jamieson, H.A.; Lerin, C.; Kalra, A.; Prabhu, V.V.; Allard, J.S.; Lopez-Lluch, G.; Lewis, K.; et al. Resveratrol improves health and survival of mice on a high-calorie diet. Nature 2006, 444, 337-342. [CrossRef] [PubMed]

134. Howitz, K.T.; Bitterman, K.J.; Cohen, H.Y.; Lamming, D.W.; Lavu, S.; Wood, J.G.; Zipkin, R.E.; Chung, P.; Kisielewski, A.; Zhang, L.L.; et al. Small molecule activators of sirtuins extend Saccharomyces cerevisiae lifespan. Nature 2003, 425, 191-196. [CrossRef] [PubMed]

135. Valenzano, D.R.; Terzibasi, E.; Genade, T.; Cattaneo, A.; Domenico, L.; Cellerino, A. Resveratrol prolongs lifespan and retards the onset of age-related markers in a short-lived vertebrate. Curr. Biol. 2006, 16, 296-300. [CrossRef]

136. Baur, J.A.; Sinclair, D.A. Therapeutic potential of resveratrol: The in vivo evidence. Nat. Rev. 2006, 5, 493-506. [CrossRef] [PubMed]

137. Wang, S.; Moustaid-Moussa, N.; Chen, L.; Mo, H.; Shastri, A.; Su, R.; Bapat, P.; Kwun, I.; Shen, C.L. Novel insights of dietary polyphenols and obesity. J. Nutr. Biochem. 2014, 25, 1-18. [CrossRef] [PubMed]

138. Kennedy, D.O.; Wightman, E.L.; Reay, J.L.; Lietz, G.; Okello, E.J.; Wilde, A.; Haskell, C.F. Effects of resveratrol on cerebral blood flow variables and cognitive performance in humans: A double-blind; placebo-controlled, crossover investigation. Am. J. Clin. Nutr. 2010, 91, 1590-1597. [CrossRef]

139. Evans, H.M.; Howe, P.R.; Wong, R.H. Effects of resveratrol on cognitive performance, mood and cerebrovascular function in post-menopausal women; a 14-week randomised placebo-controlled intervention trial. Nutrients 2017, 9, 27. [CrossRef]

140. Thaung Zaw, J.J.; Howe, P.R.C.; Wong, R.H.X. Sustained cerebrovascular and cognitive benefits of resveratrol in postmenopausal women. Nutrients 2020, 12, 828. [CrossRef]

141. Huhn, S.; Beyer, F.; Zhang, R.; Lampe, L.; Grothe, J.; Kratzsch, J.; Willenberg, A.; Breitfeld, J.; Kovacs, P.; Stumvoll, M.; et al. Effects of resveratrol on memory performance; hippocampus connectivity and microstructure in older adults-A randomized controlled trial. Neuroimage 2018, 174, 177-190. [CrossRef]

142. Farzaei, M.H.; Rahimi, R.; Nikfar, S.; Abdollahi, M. Effect of resveratrol on cognitive and memory performance and mood: A meta-analysis of 225 patients. Pharmacol. Res. 2018, 128, 338-344. [CrossRef]

143. Marx, W.; Kelly, J.T.; Marshall, S.; Cutajar, J.; Annois, B.; Pipingas, A.; Tierney, A.; Itsiopoulos, C. Effect of resveratrol supplementation on cognitive performance and mood in adults: A systematic literature review and meta-analysis of randomized controlled trials. Nutr. Rev. 2018, 76, 432-443. [CrossRef] [PubMed]

144. Losso, J.N.; Truax, R.E.; Richard, G. Trans-resveratrol inhibits hyperglycemia-induced inflammation and connexin downregulation in retinal pigment epithelial cells. J. Agric. Food Chem. 2010, 58, 8246-8252. [CrossRef]

145. Pintea, A.; Rugina, D.; Pop, R.; Bunea, A.; Socaciu, C.; Diehl, H.A. Antioxidant effect of trans-resveratrol in cultured human retinal pigment epithelial cells. J. Ocul. Pharmacol. Ther. 2011, 27, 315-321. [CrossRef] [PubMed]

146. Sheu, S.J.; Liu, N.C.; Chen, J.L. Resveratrol protects human retinal pigment epithelial cells from acrolein-induced damage. J. Ocul. Pharmacol. Ther. 2010, 26, 231-236. [CrossRef] [PubMed]

147. Kubota, S.; Kurihara, T.; Mochimaru, H.; Satofuka, S.; Noda, K.; Ozawa, Y.; Oike, Y.; Ishida, S.; Tsubota, K. Prevention of ocular inflammation in endotoxin-induced uveitis with resveratrol by inhibiting oxidative damage and nuclear factor-kappaB activation. Investig. Ophthalmol. Vis. Sci. 2009, 50, 3512-3519. [CrossRef]

148. Ren, B.; Kwah, M.X.; Liu, C.; Ma, Z.; Shanmugam, M.K.; Ding, L.; Xiang, X.; Ho, P.C.; Wang, L.; Ong, P.S.; et al. Resveratrol for cancer therapy: Challenges and future perspectives. Cancer Let. 2021, 515, 63-72. [CrossRef]

149. Visioli, F. The resveratrol fiasco. Pharmacol. Res. 2014, 90, 87. [CrossRef]

150. Jones, A.W.; Jönsson, K.A.; Kechagias, S. Effect of high-fat, high-protein, and high-carbohydrate meals on the pharmacokinetics of a small dose of ethanol. Br. J. Clin. Pharmacol. 1997, 44, 521-526. [CrossRef] [PubMed]

151. Mukamal, K.J.; Conigrave, K.M.; Mittleman, M.A.; Camargo, C.A.; Stampfer, M.J.; Willett, W.C.; Rimm, E.B. Roles of drinking pattern and type of alcohol consumed in coronary heart disease in men. N. Engl. J. Med. 2003, 348, 109-118. [CrossRef]

152. Homann, N.; Jousimies-Somer, H.; Jokelainen, K.; Heine, R.; Salaspuro, M. High acetaldehyde levels in saliva after ethanol consumption: Methodological aspects and pathogenetic implications. Carcinogenesis 1997, 18, 1739-1743. [CrossRef] 
153. Boban, M.; Stockley, C.; Teissedre, P.; Restani, P.; Fradera, U.; Stein-Hammer, C.; Ruf, J. Drinking pattern of wine and effects on human health: Why should we drink moderately and with meals? Food Funct. 2016, 7, 2937-2942. [CrossRef]

154. Rifler, J.-P. Is a meal without wine good for health? Diseases 2018, 6, 105. [CrossRef] [PubMed]

155. Sluik, D.; Jankovic, N.; O’Doherty, M.G.; Geelen, A.; Schöttker, B.; Rolandsson, O.; Kiefte-de Jong, J.; Ferrieres, J.; Bamia, C.; Fransen, H.P.; et al. Alcoholic beverage preference and dietary habits in elderly across Europe: Analyses within the consortium on health and ageing: Network of cohorts in Europe and the United States (CHANCES) Project. PLoS ONE 2016, 11, e0161603. [CrossRef] [PubMed]

156. Burke, V.; Puddey, I.B.; Beilin, L.J. Mortality associated with wines, beers, and spirits. Australian data suggest that choice of beverage relates to lifestyle and personality. BMJ 1995, 311, 1166. [CrossRef] [PubMed]

157. Männistö, S.; Uusitalo, K.; Roos, E.; Fogelholm, M.; Pietinen, P. Alcohol beverage drinking; diet and body mass index in a cross-sectional survey. Eur. J. Clin. Nutr. 1997, 51, 326-332. [CrossRef] [PubMed]

158. Tjønneland, A.; Grønbaek, M.; Stripp, C.; Overvad, K. Wine intake and diet in a random sample of 48763 Danish men and women. Am. J. Clin. Nutr. 1999, 69, 49-54. [CrossRef] [PubMed]

159. Sluik, D.; van Lee, L.; Geelen, A.; Feskens, E.J. Alcoholic beverage preference and diet in a representative Dutch population: The Dutch national food consumption survey 2007-2010. Eur. J. Clin. Nutr. 2014, 68, 287-294. [CrossRef]

160. Chatenoud, L.; Negri, E.; La Vecchia, C.; Volpato, O.; Franceschi, S. Wine drinking and diet in Italy. Eur. J. Clin. Nutr. 2000, 54, 177-179. [CrossRef]

161. Alcácera, M.A.; Marques-Lopes, I.; Fajó-Pascual, M.; Foncillas, J.P.; Carmona-Torre, F.; Martínez-González, M.A. Alcoholic beverage preference and dietary pattern in Spanish university graduates: The SUN cohort study. Eur. J. Clin. Nutr. 2008, 62, 1178-1186. [CrossRef]

162. Carmona-Torre, F.A.; García-Arellano, A.; Marques-Lopes, I.; Basora, J.; Corella, D.; Gómez-Gracia, E.; Fiol, M.; Covas, M.I.; Aros, F.; Conde, M.; et al. Relationship of alcoholic beverage consumption to food habits in a Mediterranean population. Am. J. Health. Promot. 2008, 23, 27-30. [CrossRef]

163. World Health Organization. Global Status Report on Alcohol and Health 2018; World Health Organization: Geneva, Switzerland, 2018.

164. GBD 2016 Alcohol Collaborators. Alcohol use and burden for 195 countries and territories, 1990-2016: A systematic analysis for the Global Burden of Disease Study 2016-ClinicalKey. Lancet 2018, 392, 1015-1035. [CrossRef]

165. International Agency for Research on Cancer (IARC). IARC Monographs on the Evaluation of Carcinogenic Risks to Humans. Volume 96-Alcohol Consumption and Ethyl Carbamate; International Agency for Research on Cancer: Lyon, France, 2010.

166. Corrao, G.; Bagnardi, V.; Zambon, A.; La Vecchia, C. A meta-analysis of alcohol consumption and the risk of 15 diseases. Prev. Med. 2004, 38, 613-619. [CrossRef]

167. Rehm, J.; Greenfield, T.K.; Rogers, J.D. Average volume of alcohol consumption, patterns of drinking, and all-cause mortality: Results from the US National Alcohol Survey. Am. J. Epidemiol. 2001, 153, 64-71. [CrossRef] [PubMed]

168. Nordqvist, C.; Holmqvist, M.; Nilsen, P.; Bendtsen, P.; Lindqvist, K. Usual drinking patterns and non-fatal injury among patients seeking emergency care. Public Health 2006, 120, 1064-1073. [CrossRef]

169. De Lange, D.W. From red wine to polyphenols and back: A journey through the history of the French Paradox. Thromb. Res. 2007, 119, 403-406. [CrossRef] [PubMed]

170. Day, N.L.; Zuo, Y.; Richardson, G.A. Prenatal alcohol use and offspring size at 10 years of age. Alcohol. Clin. Exp. Res. 1999, 23, 863-869. [CrossRef]

171. Olson, H.C.; Streissguth, A.P.; Sampson, P.D. Association of prenatal alcohol exposure with behavioural and learning problems in early adolescence. J. Am. Acad. Child Adol. Psych. 1997, 36, 1187-1194. [CrossRef]

172. Anderson, P.; Baumberg, B. Alcohol in Europe: A Report for the European Commission; Institute of Alcohol Studies: London, UK, 2006.

173. Fiore, M.; Messina, M.P.; Petrella, C.; D’Angelo, A.; Greco, A.; Ralli, M.; Ferraguti, G.; Tarani, L.; Vitali, M.; Ceccanti, M. Antioxidant properties of plant polyphenols in the counteraction of alcohol abuse induced damage: Impact on the Mediterranean diet. J. Funct. Foods 2020, 71, 104012. [CrossRef]

174. Aranceta-Bartrina, J.; Partearroyo, T.; López-Sobaler, A.M.; Ortega, R.M.; Varela-Moreiras, G.; Serra-Majem, L.; Pérez-Rodrigo, C. The Collaborative Group for the Dietary Guidelines for the Spanish Population (SENC). Updating the Food-Based Dietary Guidelines for the Spanish Population: The Spanish Society of Community Nutrition (SENC) Proposal. Nutrients 2019, 11, 2675. [CrossRef]

175. Stamler, J. Toward a modern Mediterranean diet for the 21st century. Nutr. Metab. Cardiovasc. Dis. 2013, 23, 1159-1162. [CrossRef] 